Supplement of Biogeosciences, 13, 2493-2509, 2016

http://www.biogeosciences.net/13/2493/2016/

doi:10.5194/bg-13-2493-2016-supplement

(C) Author(s) 2016. CC Attribution 3.0 License.

(c) (i)

Supplement of

\title{
What is the $P$ value of Siberian soils? Soil phosphorus status in south-western Siberia and comparison with a global data set
}

Félix Brédoire et al.

Correspondence to: Félix Brédoire (felix.bredoire@ nancy.inra.fr)

The copyright of individual parts of the supplement might differ from the CC-BY 3.0 licence. 
Table S1: Detailed climatic features of the study sites. Data averaged over the period 1981-2010. The data presented for each site come from the closest weather stations.

\begin{tabular}{llrrrrrr}
\hline Variable & Period & BAR & CHE & KRA & SAE & SAW & TOM \\
\hline WMO index of the station & & 29838 & 29539 & 29915 & 29745 & 29736 & 29430 \\
Distance site-station $(\mathrm{km})$ & & 4 & 28 & 76 & 18 & 64 & 38 \\
\hline Air Temperature $\left({ }^{\circ} \mathrm{C}\right)$ & MAT & 2.7 & 1.3 & 2.9 & 2.3 & 1.2 & 0.9 \\
& DJF & -14.1 & -15.2 & -15.1 & -15.4 & -17.6 & -15.6 \\
& MAM & 3.4 & 2.0 & 3.4 & 3.4 & 2.8 & 1.6 \\
& JJA & 18.3 & 17.0 & 19.7 & 17.4 & 16.9 & 16.7 \\
& SON & 2.8 & 1.2 & 3.2 & 3.0 & 2.2 & 0.8 \\
\hline Precipitation (mm) & MAP & 431.5 & 509.8 & 324.5 & 432.3 & 453.0 & 566.5 \\
& DJF & 69.8 & 84.5 & 53.2 & 54.3 & 66.1 & 104.7 \\
& MAM & 85.1 & 91.3 & 58.2 & 78.9 & 75.1 & 98.2 \\
& JJA & 166.6 & 184.8 & 135.3 & 182.2 & 168.8 & 202.9 \\
& SON & 107.7 & 146.4 & 76.1 & 106.1 & 115.9 & 157.2 \\
\hline Snow Height $(\mathrm{cm})$ & climax & 48.8 & 42.5 & 18.8 & 38.0 & 54.3 & 70.6 \\
Snow Cover Duration $1 \mathrm{~cm}($ days) & year & 157.2 & 167.6 & 141.9 & 144.5 & 149.5 & 178.1 \\
Snow Cover Duration $20 \mathrm{~cm}($ days) & year & 108.3 & 118.3 & 25.2 & 88.3 & 116.4 & 145.5 \\
\hline Soil Temperature at $20 \mathrm{~cm}\left({ }^{\circ} \mathrm{C}\right)$ & DJF & -1.5 & & -6.0 & & & -0.4 \\
& MAM & 4.3 & & 4.0 & & & 2.4 \\
& JJA & 18.9 & & 20.3 & & & 16.4 \\
Average depth of soil frozen $(\mathrm{m})$ & SON & 6.5 & & 7.3 & & 5.8 \\
\hline DJF & year & 86.8 & & 130.1 & & 44.5 \\
\hline
\end{tabular}

WMO: World Meteorological Organization; MAT: mean annual temperature; MAP: mean annual precipitations; D, J, F, M, A, M, J, J, A, S, O and N are the months of the year

*climax: maximum snow cover depth, mean snow depth between mid-February and mid-March 


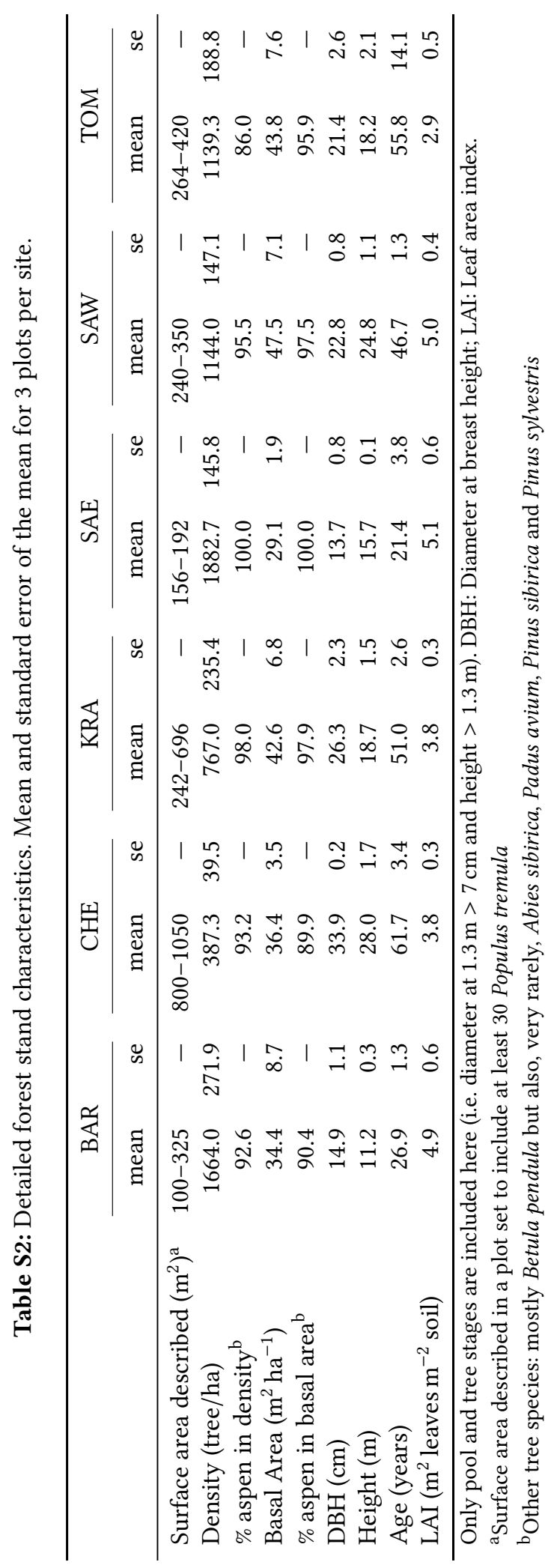




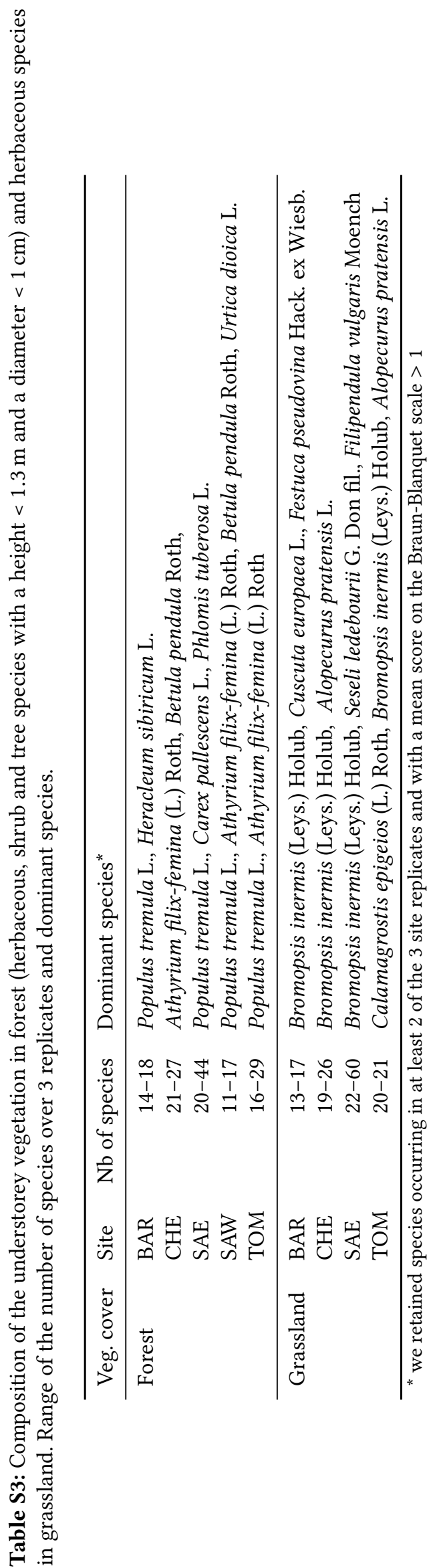




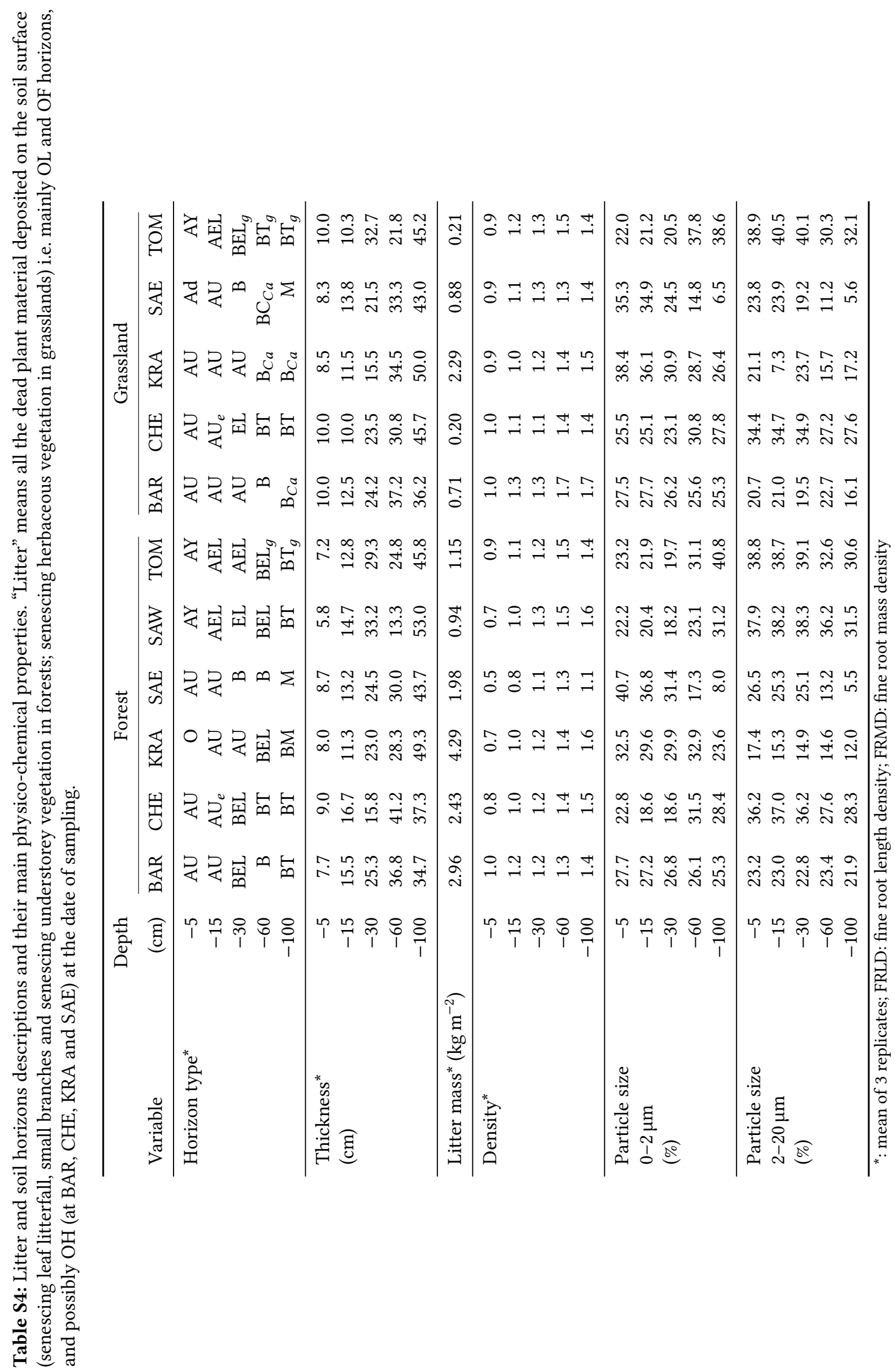




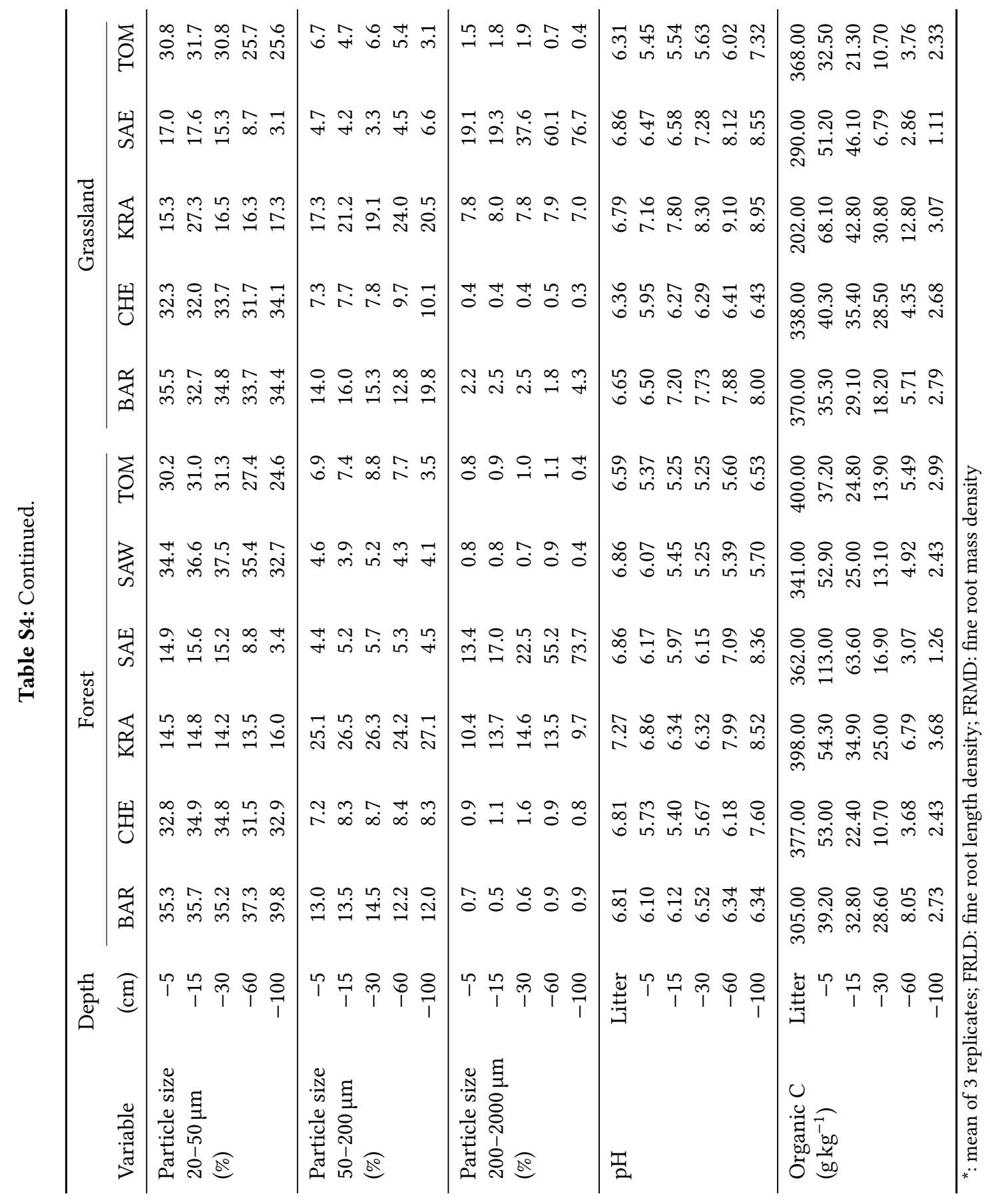




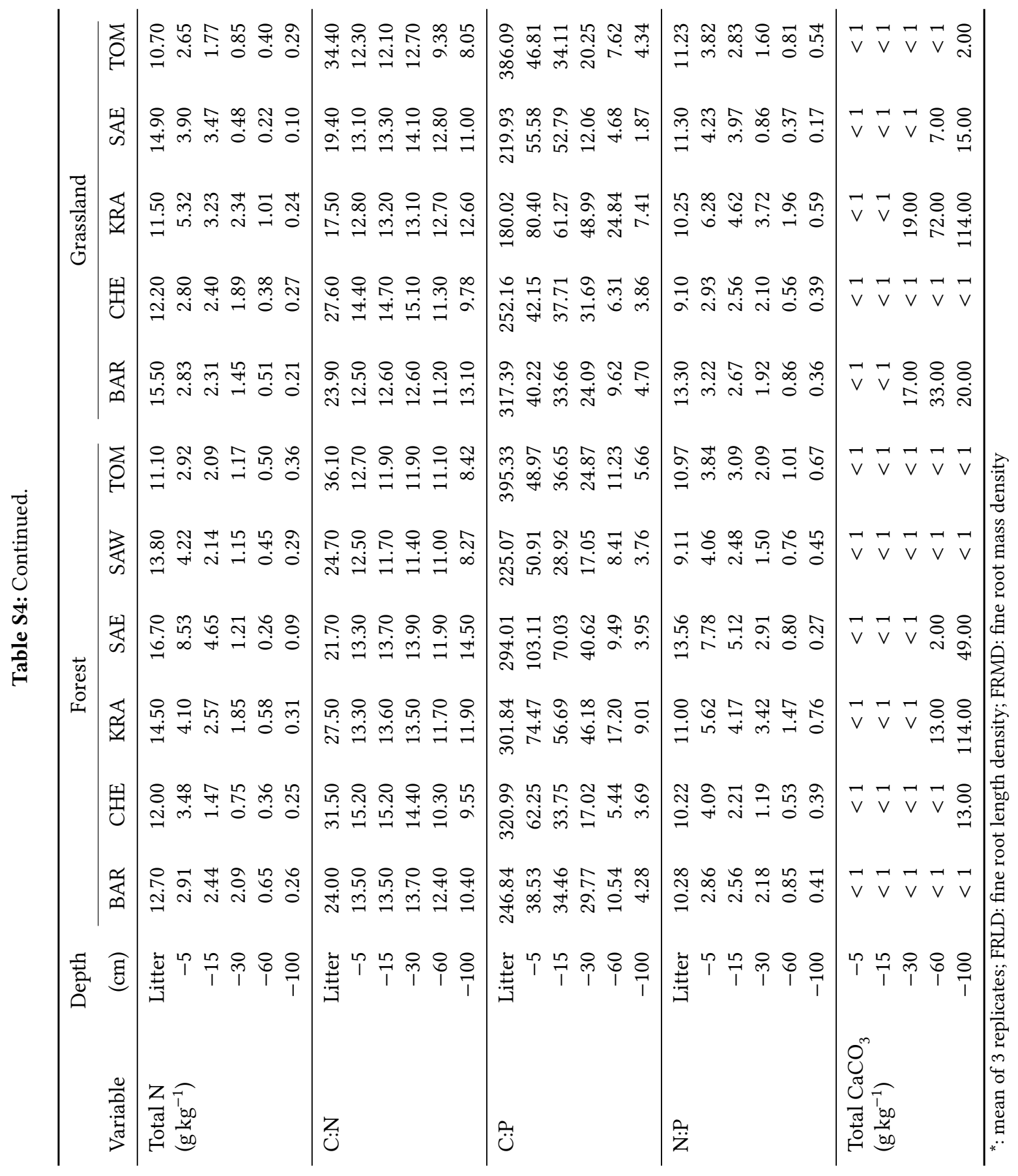




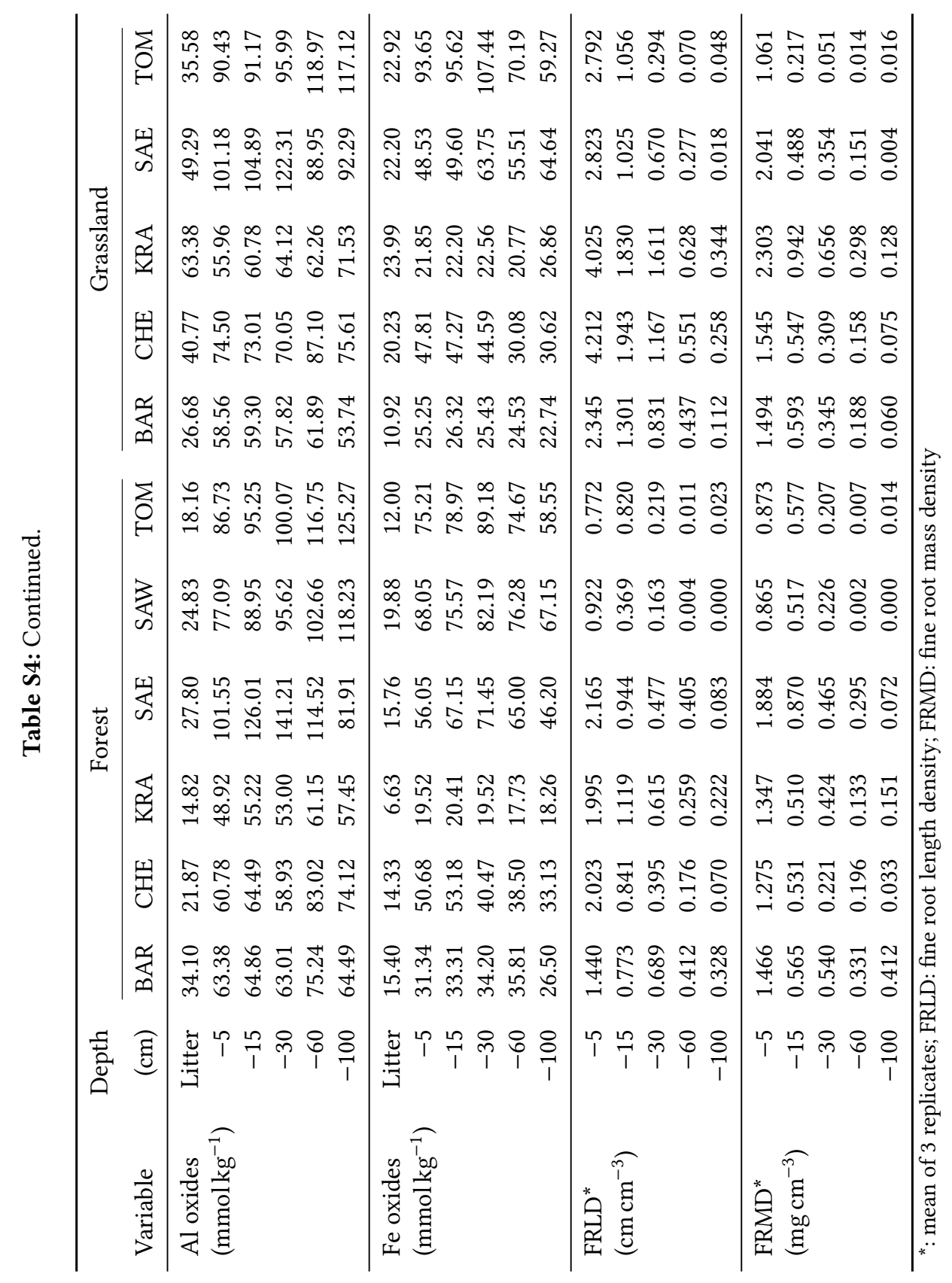


Table S5: Parameters $m$ and $n$ from the model of $r(t) / R$ (Eq. 4). "Litter" means all the dead plant material deposited on the soil surface (senescing leaf litterfall, small branches and senescing understorey vegetation in forests; senescing herbaceous vegetation in grasslands) i.e. mainly OL and OF horizons, and possibly $\mathrm{OH}$ (at BAR, CHE, KRA and SAE) at the date of sampling.

\begin{tabular}{|c|c|c|c|c|c|c|c|c|c|c|c|c|}
\hline & \multirow{2}{*}{$\begin{array}{r}\text { Depth } \\
(\mathrm{cm})\end{array}$} & \multicolumn{6}{|c|}{ Forest } & \multicolumn{5}{|c|}{ Grassland } \\
\hline & & BAR & $\mathrm{CHE}$ & KRA & SAE & SAW & TOM & BAR & $\mathrm{CHE}$ & KRA & SAE & TOM \\
\hline \multirow[t]{6}{*}{$m$} & Litter & 0.924 & 0.962 & 0.955 & 0.953 & 0.975 & 0.978 & 0.984 & 0.958 & 0.949 & 0.969 & 1.005 \\
\hline & -5 & 0.726 & 1.024 & 0.793 & 0.901 & 0.953 & 0.878 & 0.635 & 0.646 & 0.861 & 0.428 & 0.745 \\
\hline & -15 & 0.651 & 0.707 & 0.556 & 0.855 & 0.926 & 0.634 & 0.241 & 0.480 & 0.401 & 0.398 & 0.510 \\
\hline & -30 & 0.526 & 0.472 & 0.420 & 0.235 & 0.522 & 0.342 & 0.161 & 0.454 & 0.319 & 0.087 & 0.198 \\
\hline & -60 & 0.212 & 0.087 & 0.113 & 0.128 & 0.153 & 0.094 & 0.072 & 0.072 & 0.287 & 0.223 & 0.036 \\
\hline & -100 & 0.114 & 0.038 & 0.077 & 0.295 & 0.085 & 0.028 & 0.086 & 0.056 & 0.101 & 0.371 & 0.034 \\
\hline \multirow[t]{6}{*}{$n$} & Litter & 0.023 & 0.028 & 0.019 & 0.027 & 0.024 & 0.010 & 0.015 & 0.000 & 0.026 & 0.033 & 0.003 \\
\hline & -5 & 0.181 & 0.212 & 0.163 & 0.155 & 0.173 & 0.385 & 0.183 & 0.225 & 0.157 & 0.226 & 0.284 \\
\hline & -15 & 0.214 & 0.291 & 0.267 & 0.213 & 0.329 & 0.326 & 0.230 & 0.254 & 0.316 & 0.313 & 0.372 \\
\hline & -30 & 0.217 & 0.313 & 0.386 & 0.318 & 0.370 & 0.408 & 0.270 & 0.288 & 0.277 & 0.282 & 0.427 \\
\hline & -60 & 0.288 & 0.334 & 0.262 & 0.397 & 0.384 & 0.392 & 0.289 & 0.349 & 0.299 & 0.201 & 0.355 \\
\hline & -100 & 0.337 & 0.304 & 0.331 & 0.290 & 0.371 & 0.240 & 0.280 & 0.313 & 0.351 & 0.307 & 0.294 \\
\hline
\end{tabular}


Table S6: Spearman's rank correlation coefficient matrix between $\mathrm{P}$ variables and selected soil properties as well as fine root (diameter $<0.8 \mathrm{~mm}$ ) densities, computed separately for each investigated soil depth. Bold coefficients are significant at $p<0.05$. Depth is in $\mathrm{cm}$. $Q w$ : phosphate ions in solution; $m$ and $n$ are the fitting parameters of Eq. 4; Pr: diffusive phosphate ions; $E$ : isotopically exchangeable phosphate ions; FRLD: fine root length density; FRMD: fine root mass density.

\begin{tabular}{|c|c|c|c|c|c|c|c|c|c|}
\hline Depth & Variable & $P_{t o t}$ & $P_{\text {org }}$ & $P_{\text {inorg }}$ & $Q w$ & $m$ & $n$ & $\operatorname{Pr}$ (1 day) & $E$ (1 day) \\
\hline \multirow[t]{17}{*}{-5} & $\mathrm{pH}$ & 0.100 & 0.191 & -0.109 & 0.382 & -0.300 & -0.700 & 0.182 & 0.182 \\
\hline & Clay fraction & 0.282 & 0.500 & -0.209 & 0.300 & -0.227 & -0.600 & 0.209 & 0.245 \\
\hline & Organic C & 0.300 & 0.682 & -0.200 & 0.791 & 0.500 & -0.773 & 0.655 & 0.673 \\
\hline & $\mathrm{CaCO}_{3}$ & na & na & na & na & na & na & na & na \\
\hline & Al oxides & 0.355 & 0.336 & -0.091 & -0.191 & 0.000 & 0.336 & -0.191 & -0.164 \\
\hline & Fe oxides & 0.036 & 0.045 & -0.073 & -0.209 & 0.373 & 0.509 & -0.109 & -0.109 \\
\hline & $\mathrm{Al}+\mathrm{Fe}$ oxides & 0.064 & 0.173 & -0.191 & -0.364 & 0.118 & 0.555 & -0.309 & -0.291 \\
\hline & $P_{t o t}$ & - & 0.345 & 0.627 & 0.527 & 0.055 & -0.409 & 0.464 & 0.527 \\
\hline & $P_{\text {org }}$ & 0.345 & - & -0.364 & 0.318 & 0.227 & -0.345 & 0.100 & 0.173 \\
\hline & $P_{\text {inorg }}$ & 0.627 & -0.364 & - & 0.191 & -0.055 & 0.009 & 0.364 & 0.336 \\
\hline & $Q w$ & 0.527 & 0.318 & 0.191 & - & 0.609 & -0.864 & 0.882 & 0.909 \\
\hline & $m$ & 0.055 & 0.227 & -0.055 & 0.609 & - & -0.318 & 0.709 & 0.709 \\
\hline & $n$ & -0.409 & -0.345 & 0.009 & -0.864 & -0.318 & - & -0.673 & -0.736 \\
\hline & $\operatorname{Pr}$ (1 day) & 0.464 & 0.100 & 0.364 & 0.882 & 0.709 & -0.673 & - & 0.982 \\
\hline & $E$ (1 day) & 0.527 & 0.173 & 0.336 & 0.909 & 0.709 & -0.736 & 0.982 & - \\
\hline & FRLD & -0.055 & 0.345 & -0.364 & -0.145 & -0.518 & 0.018 & -0.445 & -0.418 \\
\hline & FRMD & 0.236 & 0.482 & -0.209 & 0.118 & -0.464 & -0.364 & -0.055 & -0.027 \\
\hline \multirow[t]{17}{*}{-15} & $\mathrm{pH}$ & 0.205 & 0.318 & -0.045 & -0.473 & -0.755 & -0.318 & -0.227 & -0.282 \\
\hline & Clay fraction & 0.296 & 0.609 & -0.291 & -0.055 & -0.373 & -0.491 & 0.009 & 0.018 \\
\hline & Organic C & 0.542 & 0.773 & -0.100 & 0.109 & -0.218 & -0.536 & 0.045 & 0.064 \\
\hline & $\mathrm{CaCO}_{3}$ & na & na & na & na & na & na & na & na \\
\hline & Al oxides & 0.333 & 0.527 & 0.036 & 0.136 & 0.282 & 0.155 & 0.209 & 0.282 \\
\hline & Fe oxides & -0.091 & 0.027 & 0.027 & 0.091 & 0.455 & 0.500 & 0.173 & 0.227 \\
\hline & $\mathrm{Al}+\mathrm{Fe}$ oxides & 0.150 & 0.336 & 0.009 & 0.155 & 0.409 & 0.245 & 0.145 & 0.227 \\
\hline & $P_{t o t}$ & - & 0.456 & 0.688 & 0.337 & 0.018 & -0.579 & 0.296 & 0.333 \\
\hline & $P_{\text {org }}$ & 0.456 & - & -0.091 & -0.027 & -0.164 & -0.118 & 0.045 & 0.073 \\
\hline & $P_{\text {inorg }}$ & 0.688 & -0.091 & - & 0.209 & 0.027 & -0.309 & 0.255 & 0.273 \\
\hline & $Q w$ & 0.337 & -0.027 & 0.209 & - & 0.855 & -0.436 & 0.600 & 0.664 \\
\hline & $m$ & 0.018 & -0.164 & 0.027 & 0.855 & - & -0.009 & 0.545 & 0.609 \\
\hline & $n$ & -0.579 & -0.118 & -0.309 & -0.436 & -0.009 & - & 0.064 & 0.000 \\
\hline & $\operatorname{Pr}$ (1 day) & 0.296 & 0.045 & 0.255 & 0.600 & 0.545 & 0.064 & - & 0.991 \\
\hline & $E$ (1 day) & 0.333 & 0.073 & 0.273 & 0.664 & 0.609 & 0.000 & 0.991 & - \\
\hline & FRLD & -0.091 & 0.264 & -0.336 & -0.636 & -0.764 & -0.145 & -0.691 & -0.736 \\
\hline & FRMD & 0.351 & 0.282 & 0.064 & 0.364 & -0.018 & -0.464 & 0.400 & 0.391 \\
\hline \multirow[t]{17}{*}{-30} & $\mathrm{pH}$ & 0.237 & 0.273 & 0.032 & 0.228 & -0.346 & -0.793 & 0.533 & 0.551 \\
\hline & Clay fraction & -0.246 & 0.136 & -0.464 & -0.036 & -0.300 & -0.391 & 0.355 & 0.282 \\
\hline & Organic C & 0.400 & 0.843 & 0.009 & 0.474 & 0.328 & -0.469 & 0.077 & 0.105 \\
\hline & $\mathrm{CaCO}_{3}$ & 0.176 & 0.324 & -0.040 & 0.027 & -0.351 & -0.512 & 0.081 & 0.081 \\
\hline & Al oxides & -0.410 & -0.564 & -0.209 & -0.400 & -0.355 & 0.318 & -0.200 & -0.291 \\
\hline & Fe oxides & -0.305 & -0.536 & 0.018 & -0.445 & -0.127 & 0.600 & -0.464 & -0.536 \\
\hline & $\mathrm{Al}+\mathrm{Fe}$ oxides & -0.465 & -0.636 & -0.209 & -0.491 & -0.245 & 0.500 & -0.400 & -0.491 \\
\hline & $P_{t o t}$ & - & 0.656 & 0.870 & 0.825 & 0.565 & -0.661 & 0.205 & 0.328 \\
\hline & $P_{\text {org }}$ & 0.656 & - & 0.282 & 0.691 & 0.573 & -0.336 & 0.009 & 0.100 \\
\hline & $P_{\text {inorg }}$ & 0.870 & 0.282 & - & 0.573 & 0.391 & -0.500 & 0.236 & 0.318 \\
\hline & $Q w$ & 0.825 & 0.691 & 0.573 & - & 0.745 & -0.545 & 0.445 & 0.555 \\
\hline & $m$ & 0.565 & 0.573 & 0.391 & 0.745 & - & -0.036 & 0.018 & 0.109 \\
\hline & $n$ & -0.661 & -0.336 & -0.500 & -0.545 & -0.036 & - & -0.473 & -0.536 \\
\hline & $\operatorname{Pr}$ (1 day) & 0.205 & 0.009 & 0.236 & 0.445 & 0.018 & -0.473 & - & 0.982 \\
\hline & $E$ (1 day) & 0.328 & 0.100 & 0.318 & 0.555 & 0.109 & -0.536 & 0.982 & - \\
\hline & FRLD & 0.387 & 0.518 & 0.073 & 0.336 & -0.173 & -0.773 & 0.236 & 0.291 \\
\hline & FRMD & 0.155 & 0.336 & -0.118 & 0.427 & 0.018 & -0.655 & 0.636 & 0.618 \\
\hline
\end{tabular}


Table S6: Continued.

\begin{tabular}{|c|c|c|c|c|c|c|c|c|c|}
\hline Depth & Variable & $P_{t o t}$ & $P_{\text {org }}$ & $P_{\text {inorg }}$ & $Q w$ & $m$ & $n$ & $\operatorname{Pr}$ (1 day) & $E$ (1 day) \\
\hline \multirow[t]{17}{*}{-60} & $\mathrm{pH}$ & -0.045 & 0.073 & -0.200 & 0.436 & 0.400 & -0.636 & -0.491 & -0.491 \\
\hline & Clay fraction & -0.145 & -0.055 & -0.082 & 0.045 & -0.555 & 0.055 & 0.782 & 0.782 \\
\hline & Organic C & 0.027 & 0.509 & -0.073 & 0.273 & 0.209 & -0.264 & 0.182 & 0.182 \\
\hline & $\mathrm{CaCO}_{3}$ & -0.312 & 0.069 & -0.461 & 0.144 & 0.327 & -0.471 & -0.649 & -0.649 \\
\hline & Al oxides & -0.264 & -0.300 & -0.127 & -0.491 & -0.191 & 0.718 & 0.100 & 0.100 \\
\hline & Fe oxides & -0.164 & -0.127 & -0.027 & -0.482 & -0.073 & 0.664 & -0.018 & -0.018 \\
\hline & $\mathrm{Al}+\mathrm{Fe}$ oxides & -0.264 & -0.245 & -0.109 & -0.564 & -0.227 & 0.718 & 0.027 & 0.027 \\
\hline & $P_{t o t}$ & - & 0.382 & 0.973 & 0.555 & 0.036 & -0.427 & 0.291 & 0.291 \\
\hline & $P_{\text {org }}$ & 0.382 & - & 0.282 & 0.518 & 0.564 & -0.327 & -0.091 & -0.091 \\
\hline & $P_{\text {inorg }}^{\circ}$ & 0.973 & 0.282 & - & 0.455 & -0.109 & -0.355 & 0.373 & 0.373 \\
\hline & $Q w$ & 0.555 & 0.518 & 0.455 & - & 0.509 & -0.809 & 0.173 & 0.173 \\
\hline & $m$ & 0.036 & 0.564 & -0.109 & 0.509 & - & -0.291 & -0.509 & -0.509 \\
\hline & $n$ & -0.427 & -0.327 & -0.355 & -0.809 & -0.291 & - & 0.100 & 0.100 \\
\hline & $\operatorname{Pr}$ (1 day) & 0.291 & -0.091 & 0.373 & 0.173 & -0.509 & 0.100 & - & 1.000 \\
\hline & $E$ (1 day) & 0.291 & -0.091 & 0.373 & 0.173 & -0.509 & 0.100 & 1.000 & - \\
\hline & FRLD & 0.318 & 0.100 & 0.164 & 0.327 & 0.191 & -0.373 & -0.145 & -0.145 \\
\hline & FRMD & 0.336 & 0.282 & 0.200 & 0.382 & 0.318 & -0.273 & -0.100 & -0.100 \\
\hline \multirow[t]{17}{*}{-100} & $\mathrm{pH}$ & -0.615 & -0.518 & -0.591 & -0.364 & 0.400 & -0.109 & -0.391 & -0.391 \\
\hline & Clay fraction & 0.308 & 0.515 & 0.251 & 0.451 & -0.847 & -0.105 & 0.852 & 0.852 \\
\hline & Organic C & -0.228 & 0.378 & -0.237 & 0.679 & -0.287 & 0.164 & 0.342 & 0.342 \\
\hline & $\mathrm{CaCO}_{3}$ & -0.673 & -0.359 & -0.676 & -0.284 & 0.387 & -0.019 & -0.387 & -0.387 \\
\hline & Al oxides & 0.041 & 0.073 & 0.009 & 0.018 & -0.309 & -0.164 & 0.427 & 0.427 \\
\hline & Fe oxides & 0.164 & -0.118 & 0.127 & -0.127 & -0.073 & -0.055 & 0.291 & 0.291 \\
\hline & $\mathrm{Al}+\mathrm{Fe}$ oxides & 0.118 & -0.009 & 0.073 & 0.000 & -0.255 & -0.145 & 0.436 & 0.436 \\
\hline & $P_{t o t}$ & - & 0.260 & 0.989 & 0.132 & -0.191 & 0.246 & 0.241 & 0.241 \\
\hline & $P_{\text {org }}$ & 0.260 & - & 0.209 & 0.409 & -0.709 & 0.227 & 0.500 & 0.500 \\
\hline & $P_{\text {inorg }}$ & 0.989 & 0.209 & - & 0.091 & -0.145 & 0.245 & 0.173 & 0.173 \\
\hline & $Q w$ & 0.132 & 0.409 & 0.091 & - & -0.227 & 0.555 & 0.736 & 0.736 \\
\hline & $m$ & -0.191 & -0.709 & -0.145 & -0.227 & - & 0.300 & -0.655 & -0.655 \\
\hline & $n$ & 0.246 & 0.227 & 0.245 & 0.555 & 0.300 & - & 0.291 & 0.291 \\
\hline & $\operatorname{Pr}$ (1 day) & 0.241 & 0.500 & 0.173 & 0.736 & -0.655 & 0.291 & - & 1.000 \\
\hline & $E$ (1 day) & 0.241 & 0.500 & 0.173 & 0.736 & -0.655 & 0.291 & 1.000 & - \\
\hline & FRLD & -0.114 & -0.009 & -0.055 & 0.173 & 0.191 & 0.273 & -0.209 & -0.209 \\
\hline & FRMD & -0.210 & 0.073 & -0.136 & 0.100 & 0.209 & 0.264 & -0.318 & -0.318 \\
\hline
\end{tabular}




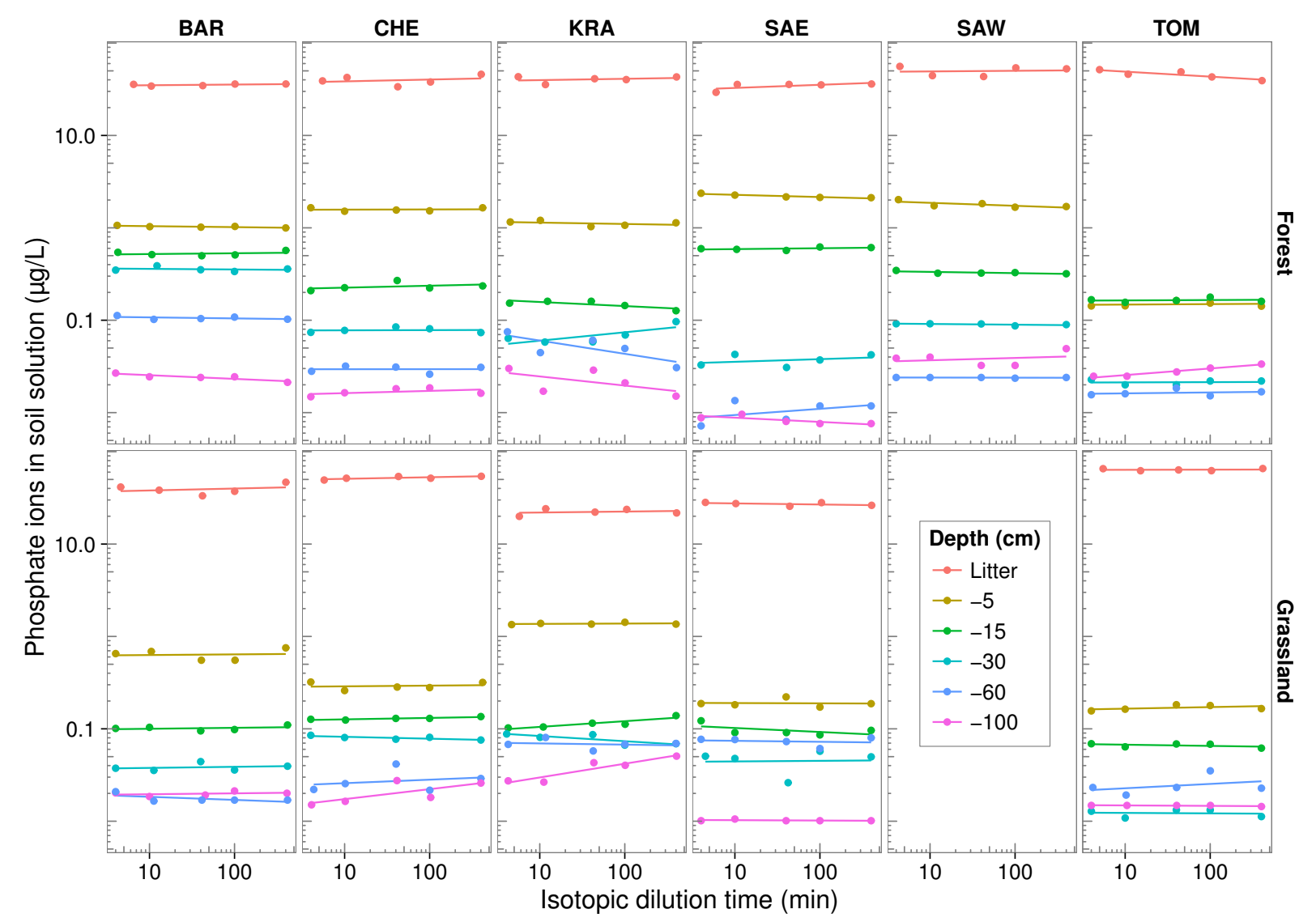

Figure S1: Measurements of the concentration of phosphate ions in soil solution during the isotopic dilution. "Litter" means all the dead plant material deposited on the soil surface (senescing leaf litterfall, small branches and senescing understorey vegetation in forests; senescing herbaceous vegetation in grasslands) i.e. mainly OL and OF horizons, and possibly OH (at BAR, CHE, KRA and SAE) at the date of sampling. 


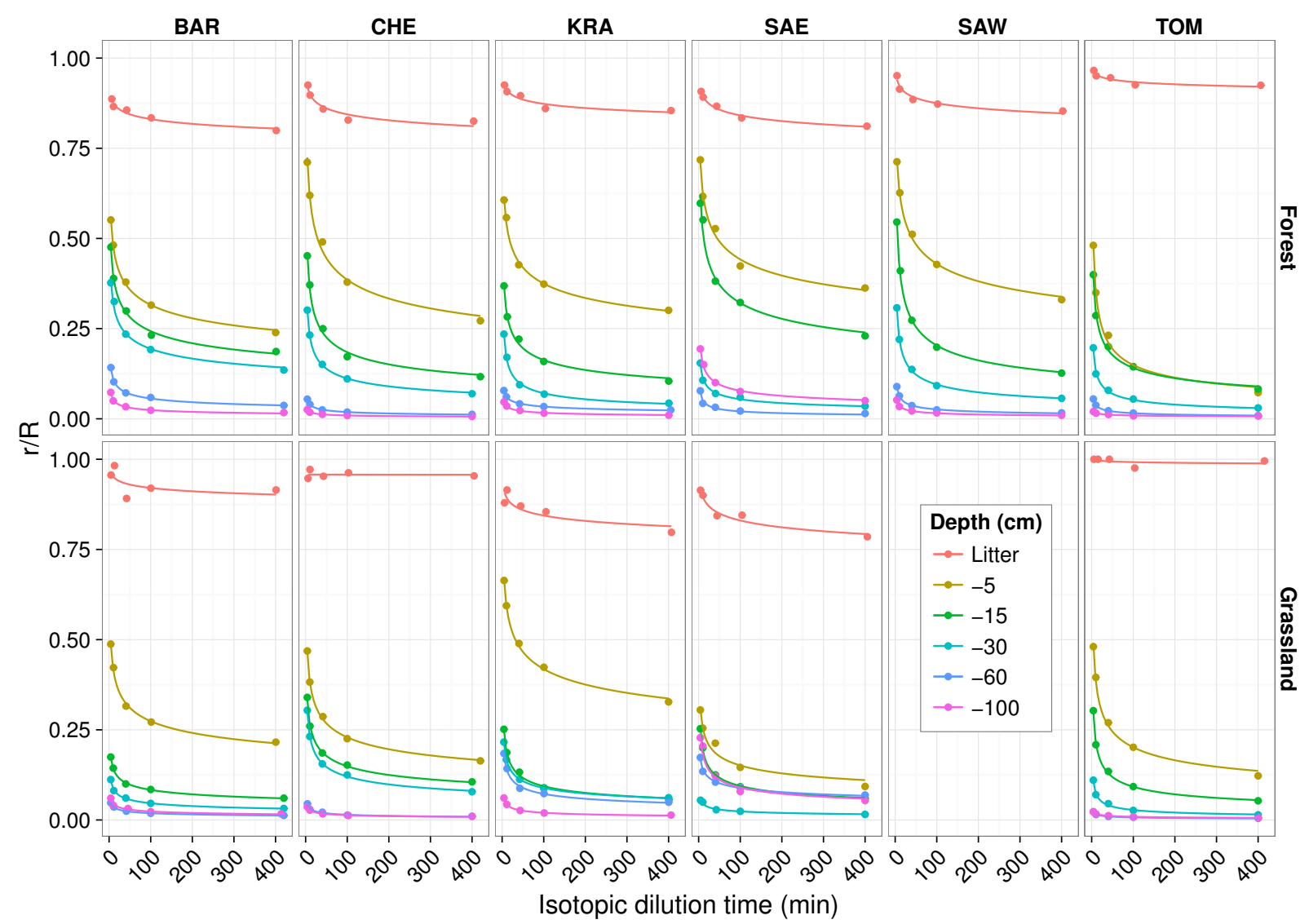

Figure S2: Fit of the model of $r(t) / R$ (Eq. 4). "Litter" means all the dead plant material deposited on the soil surface (senescing leaf litterfall, small branches and senescing understorey vegetation in forests; senescing herbaceous vegetation in grasslands) i.e. mainly OL and OF horizons, and possibly OH (at BAR, CHE, KRA and SAE) at the date of sampling. 

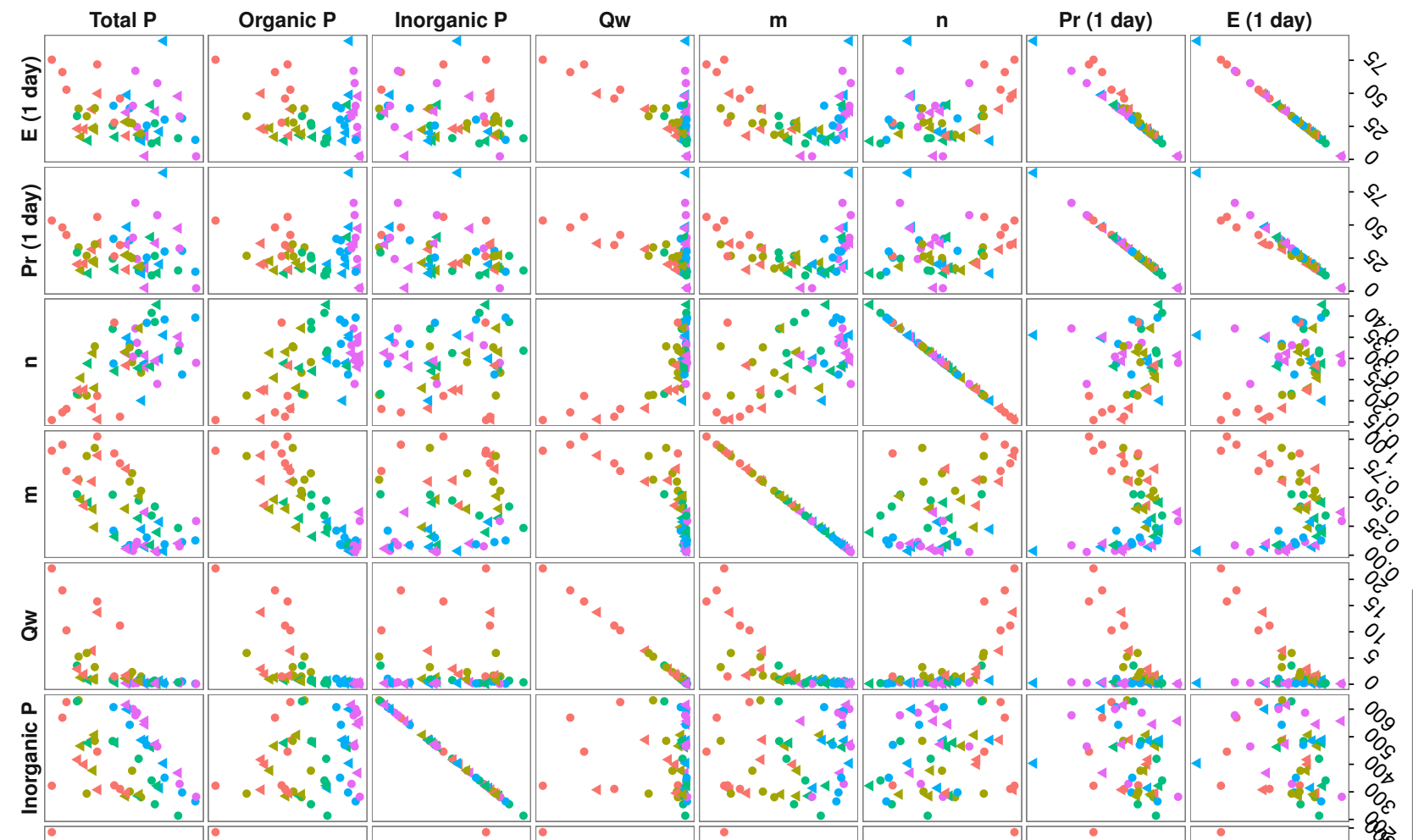

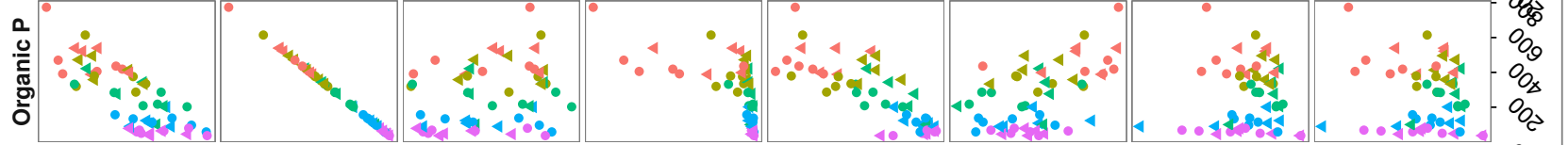

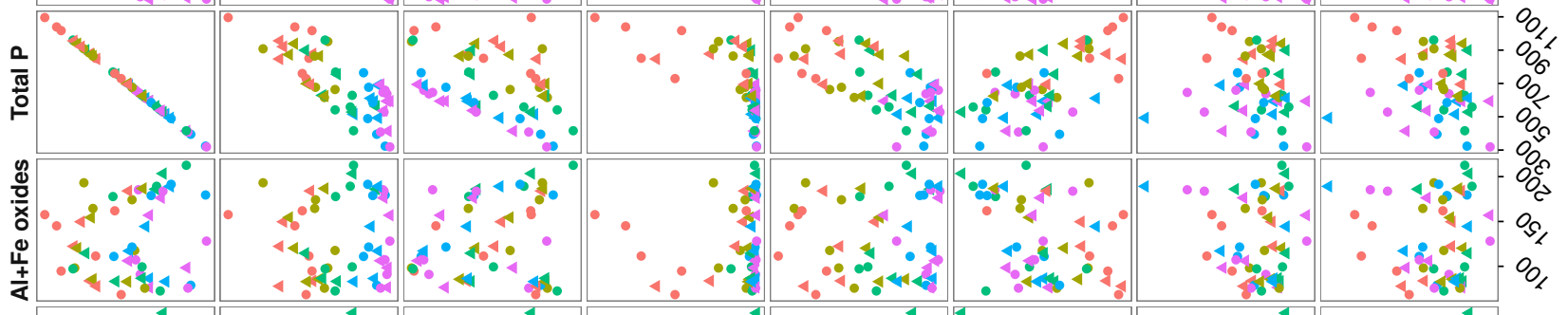

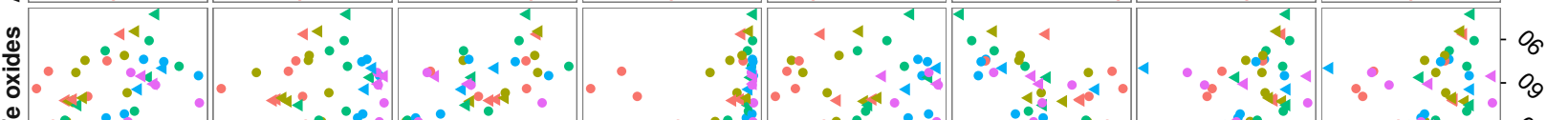

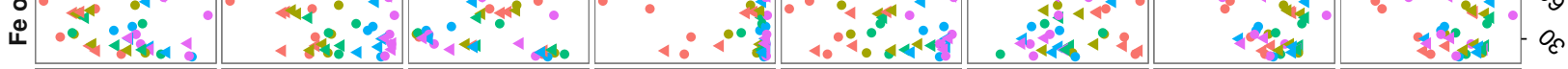

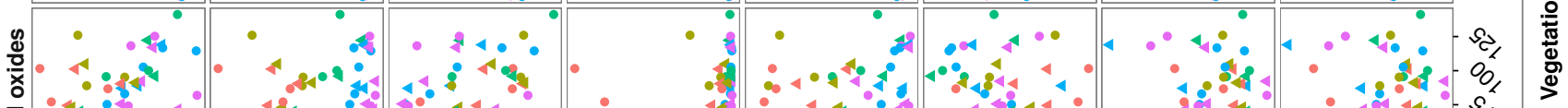

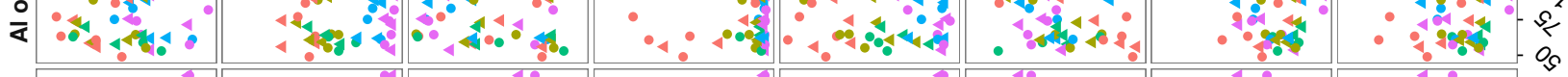

ర్ల్ర

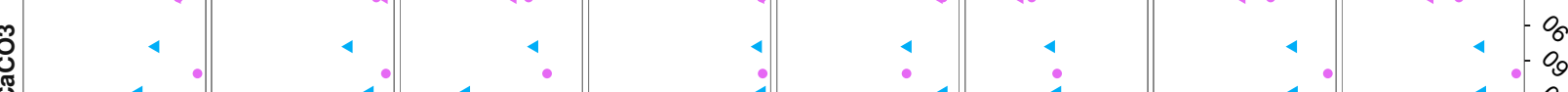

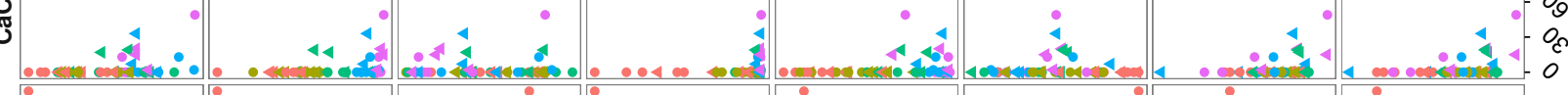

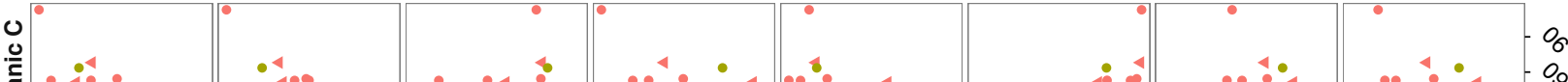

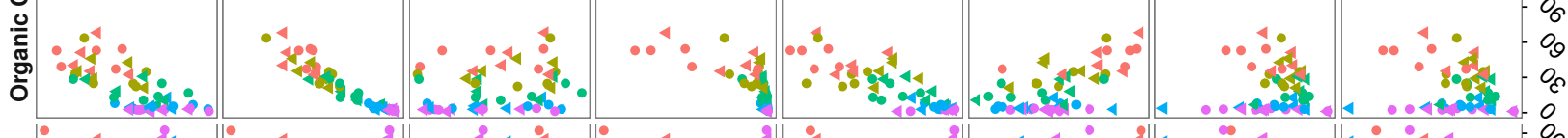

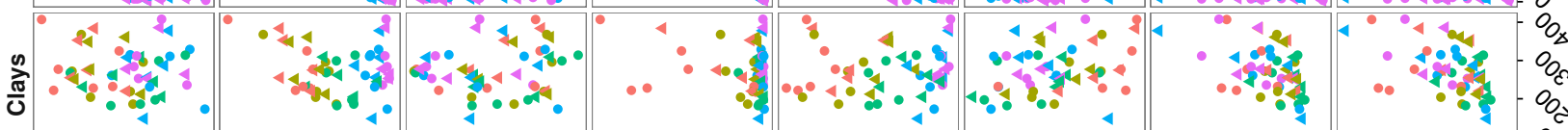

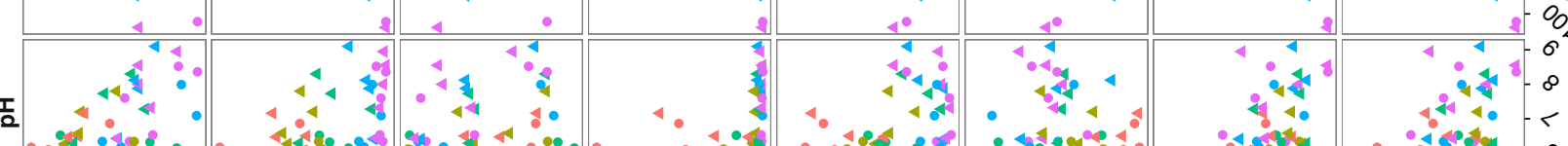

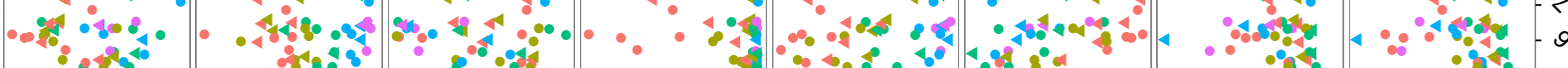

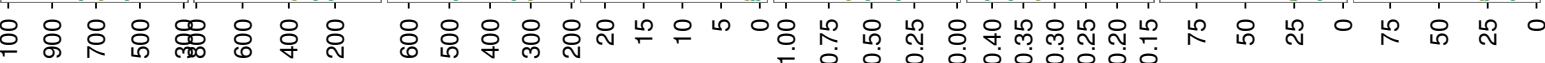



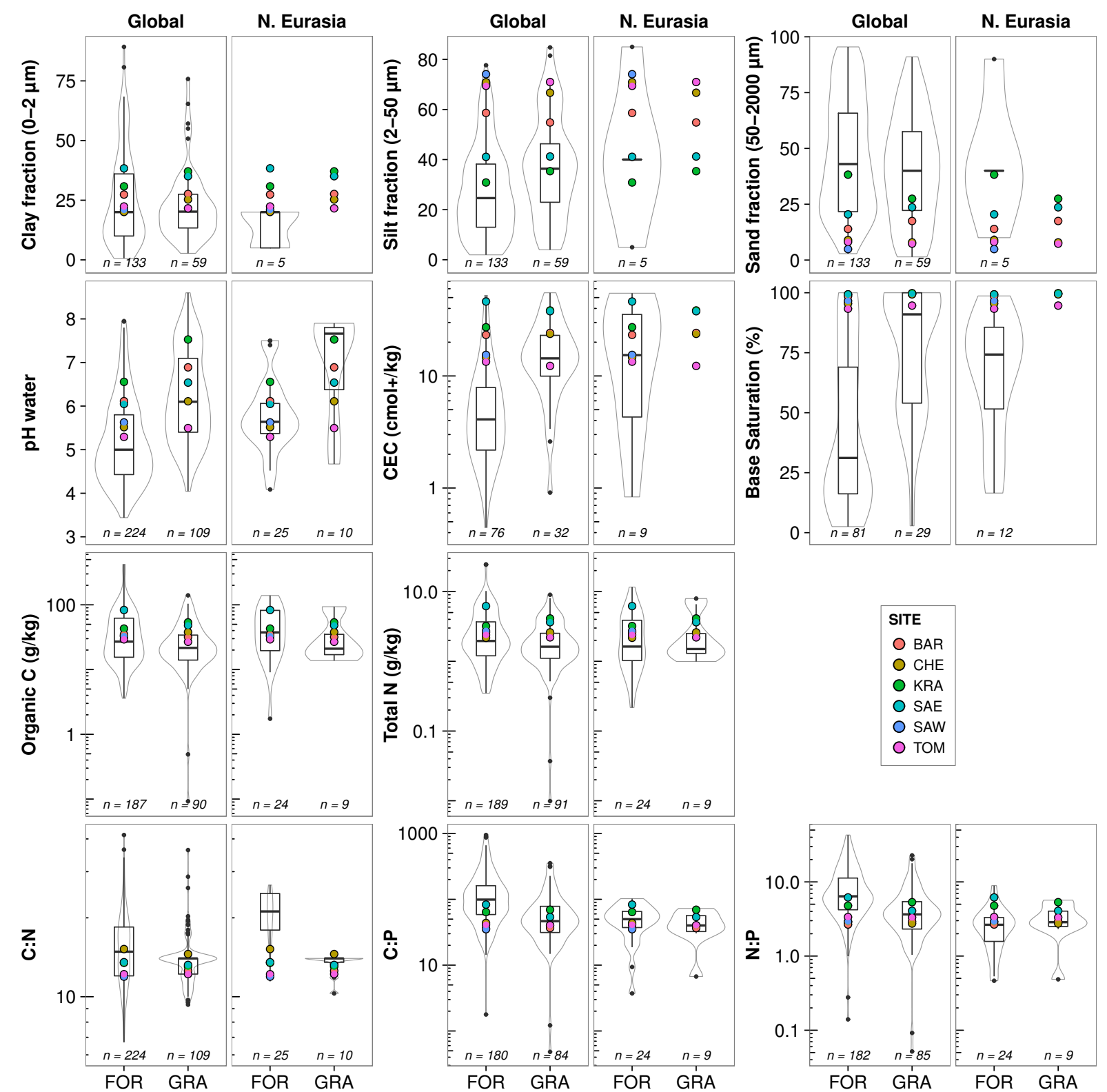

Figure S4: Comparison of selected soil properties in topsoils (about 0 to $-20 \mathrm{~cm}$ ) of SW Siberia (coloured dots) and different vegetation types (FOR: forests; GRA: grasslands-box- and violin-plots) at the global scale and in Northern Eurasia (N. Eurasia), along broad gradients of soil and geology contexts. Parameters with less than 5 values available in our compilation dataset are not displayed. The " $n$ " provided indicates the number of individual points used to build the box- and the violin-plots. 


\section{References of the global data compilation}

Abekoe, M. K. and Sahrawat, K. L. (2003). Long-term cropping effect on phosphorus fractions in an ultisol of the humid forest zone in West Africa. Commun. Soil Sci. Plant Anal. 34, 427-437.

Achat, D. L., Bakker, M. R., Augusto, L., Derrien, D., Gallegos, N., Lashchinskiy, N., Milin, S., Nikitich, P., Raudina, T., Rusalimova, O., Zeller, B., and Barsukov, P. (2013). Phosphorus status of soils from contrasting forested ecosystems in southwestern Siberia: effects of microbiological and physicochemical properties. Biogeosciences 10, 733-752. DOI: $10.5194 / \mathrm{bg}-10-733-2013$.

Achat, D. L., Pousse, N., Nicolas, M., Brédoire, F., and Augusto, L. (2016). Soil properties controlling inorganic phosphorus availability - Generic results from a national forest network and a global compilation of the literature. In preparation.

Achat, D. L., Augusto, L., Morel, C., and Bakker, M. R. (2011). Predicting available phosphate ions from physical-chemical soil properties in acidic sandy soils under pine forests. F. Soils Sediments 11 (3), 452-466. DOI: 10.1007/s11368-010-0329-9.

Achat, D. L., Bakker, M. R., Augusto, L., Saur, E., Dousseron, L., and Morel, C. (2009). Evaluation of the phosphorus status of P-deficient podzols in temperate pine stands: combining isotopic dilution and extraction methods. Biogeochemistry 92 (3), 183-200. DOI: 10.1007/s10533-008-9283-7.

Achat, D. L., Daumer, M.-L., Sperandio, M., Santellani, A.-C., and Morel, C. (2014). Solubility and mobility of phosphorus recycled from dairy effluents and pig manures in incubated soils with different characteristics. Nutri. Cycl. Agroecosyst. 99.1-3, 1-15. DoI: 10.1007/s10705-014-9614-0.

Agbenin, J. O. and Goladi, J. T. (1998). Dynamics of phosphorus fractions in a savanna Alfisol under continuous cultivation. Soil Use and Management 14, 59-64.

Agbenin, J. O. and Igbokwe, S. O. (2006). Effect of soil-dung manure incubation on the solubility and retention of applied phosphate by a weathered tropical semi-arid soil. Geoderma 133, 191-203. DoI: 10.1016/j .geoderma. 2005.07 .006$.

Agbenin, J. O. and Tiessen, H. (1994). Phosphorus Transformations in a Toposequence of Lithosols and Cambisols from Semiarid Northeastern Brazil. Geoderma 62, 345-362. DoI: 10.1016/0016-7061 (94)90098-1.

Aguiar, A. D. F., Candido, C. S., Carvalho, C. S., Monroe, P. H. M., and Moura, E. G. de (2013). Organic matter fraction and pools of phosphorus as indicators of the impact of land use in the Amazonian periphery. Ecol. Indic. 30, 158-164. DoI: 10.1016/j . ecolind.2013.02.010.

Almond, P. C. and Tonkin, P. J. (1999). Pedogenesis by upbuilding in an extreme leaching and weathering environment, and slow loess accretion, south Westland, New Zealand. Geoderma 92, 1-36. DoI: 10.1016/ S0016-7061 (99)00016-6.

Alt, F., Oelmann, Y., Herold, N., Schrumpf, M., and Wilcke, W. (2011). Phosphorus partitioning in grassland and forest soils of Germany as related to land-use type, management intensity, and land use-related $\mathrm{pH}$. $\mathrm{F}$. Plant Nutr. Soil Sci. 174, 195-209. DoI: 10.1002/jpln.201000142.

Andersohn, C. (1996). Phosphate cycles in energy crop systems with emphasis on the availability of different phosphate fractions in the soil. Plant Soil 184, 11-21. DoI: 10.1007/Bf00029270.

Andriamaniraka, H., Rabeharisoa, L., Michellon, R., Moussa, N., and Morel, C. (2010). Influence de différents systèmes de culture sur la productivité de sols cultivés des Hautes Terres de Madagascar et conséquences pour le bilan de phosphore. Étude et Gestion des Sols 17.2, 119-130.

Aoki, M., Fujii, K., and Kitayama, K. (2012). Environmental Control of Root Exudation of Low-Molecular Weight Organic Acids in Tropical Rainforests. Ecosystems 15, 1194-1203. DoI: 10.1007/s10021-012-9575-6.

Aulakh, M. S., Kabba, B. S., Baddesha, H. S., Bahl, G. S., and Gill, M. P. S. (2003). Crop yields and phosphorus fertilizer transformations after 25 years of applications to a subtropical soil under groundnut-based cropping systems. Field Crops Research 83, 283-296.

Bah, A. R., Zaharah, A. R., Hussin, A., Husni, M. H., and Halimi, M. S. (2003). Phosphorus Status of Amended Soil as Assessed by Conventional and Isotopic Methods. Commun. Soil Sci. Plant Anal. 34.17-18, 2659-2681. DOI: 10.1081/css-120024792.

Basamba, T. A., Barrios, E., Singh, B. R., and Rao, I. M. (2007). Impact of planted fallows and a crop rotation on nitrogen mineralization and phosphorus and organic matter fractions on a Colombian volcanic-ash soil. Nutri. Cycl. Agroecosyst. 77, 127-141. DOI: 10.1007/s10705-006-9050-x.

Beck, M. A. and Elsenbeer, H. (1999). Biogeochemical cycles of soil phosphorus in southern Alpine spodosols. Geoderma 91, 249-260.

Beck, M. A. and Sanchez, P. A. (1996). Soil phosphorus movement and budget after 13 years of fertilized cultivation in the Amazon basin. Plant Soil 184, 23-31. 
Blake, L., Johnston, A. E., Poulton, P. R., and Goulding, K. W. T. (2003). Changes in soil phosphorus fractions following positive and negative phosphorus balances for long periods. Plant Soil 254, 245-261. DOI: 10 . 1023/A : 1025544817872 .

Boldeskul, A. G. (2002). The forms of phosphorus compounds in brown soils of fir-broad-leaved forests of the southern Primor'e Region. Eurasian Soil Sci. 35, 71-78.

Borda, T., Celi, L., Bünemann, E. K., Oberson, A., Frossard, E., and Barberis, E. (2014). Fertilization Strategies Affect Phosphorus Forms and Release from Soils and Suspended Solids. Fournal of Environment Quality 43.3, 1024. DOI: $10.2134 /$ jeq2013.11.0436.

Brandtberg, P. O., Davis, M. R., Clinton, P. W., Condron, L. M., and Allen, R. B. (2010). Forms of soil phosphorus affected by stand development of mountain beech (Nothofagus) forests in New Zealand. Geoderma 157, 228234.

Bühler, S., Oberson, A., Rao, I. M., Friesen, D. K., and Frossard, E. (2002). Sequential Phosphorus Extraction of a P-Labeled Oxisol under Contrasting Agricultural Systems. Soil Sci. Soc. Am. 7. 66.3, 868-877. Dor: 10.2136/ sssaj2002.0868.

Bühler, S., Oberson, A., Sinaj, S., Friesen, D. K., and Frossard, E. (2003). Isotope methods for assessing plant available phosphorus in acid tropical soils. Eur. F. Soil Sci. 54.3, 605-616. DOI: 10.1046/ j .1365-2389.2003.00542 .x.

Bünemann, E. K., Marschner, P., McNeill, A., and McLaughlin, M. (2007). Measuring rates of gross and net mineralisation of organic phosphorus in soils. Soil Biol. Biochem. 39.4, 900-913. Dor: 10.1016/j . soilbio. 2006.10.009.

Bünemann, E. K., Steinebrunner, F., Smithson, P. C., Frossard, E., and Oberson, A. (2004). Phosphorus Dynamics in a Highly Weathered Soil as Revealed by Isotopic Labeling Techniques. Soil Sci. Soc. Am. J. 68.5, 1645-1655. DOI: $10.2136 /$ sssaj2004.1645.

Bünemann, E., Oberson, A., Liebisch, F., Keller, F., Annaheim, K., Huguenin-Elie, O., and Frossard, E. (2012). Rapid microbial phosphorus immobilization dominates gross phosphorus fluxes in a grassland soil with low inorganic phosphorus availability. Soil Biol. Biochem. 51, 84-95. Dor: 10.1016/j . soilbio.2012.04.012.

Bünemann, E. K. (2003). Phosphorus dynamics in a ferralsol under maize-fallow rotations: The role of the soil microbial biomass. PhD thesis. ETH, Swiss Federal Institute of Technology.

Campbell, C. A., Schnitzer, M., Stewart, J. W. B., Biederbeck, V. O., and Selles, F. (1986). Effect of manure and P fertilizer on properties of a black chernozem in southern Saskatchewan. Can. F. Soil Sci. 66, 601-613.

Cassagne, N., Remaury, M., Gauquelin, T., and Fabre, A. (2000). Forms and profile distribution of soil phosphorus in alpine Inceptisols and Spodosols (Pyrenees, France). Geoderma 95, 161-172.

Chacon, N. and Dezzeo, N. (2004). Phosphorus fractions and sorption processes in soil samples taken in a forestsavanna sequence of the Gran Sabana in southern Venezuela. Biol. Fertil. Soils 40, 14-19.

Chacon, N., Dezzeo, N., Munoz, B., and Rodriguez, J. M. (2005). Implications of soil organic carbon and the biogeochemistry of iron and aluminum on soil phosphorus distribution in flooded forests of the lower Orinoco River, Venezuela. Biogeochemistry 73, 555-566. DoI: 10.1007/s10533-004-1773-7.

Chapuis-Lardy, L., Ramiandrisoa, R. S., Randriamanantsoa, L., Morel, C., Rabeharisoa, L., and Blanchart, E. (2009). Modification of P availability by endogeic earthworms (Glossoscolecidae) in Ferralsols of the Malagasy Highlands. Biol. Fertil. Soils 45.4, 415-422. DOI: 10.1007/s00374-008-0350-y.

Chapuis-Lardy, L., Vanderhoeven, S., Dassonville, N., Koutika, L. S., and Meerts, P. (2006). Effect of the exotic invasive plant Solidago gigantea on soil phosphorus status. Biol. Fertil. Soils 42, 481-489. DoI: 10 . $1007 /$ s00374-005-0039-4.

Chen, C. R., Condron, L. M., Davis, M. R., and Sherlock, R. R. (2003). Seasonal changes in soil phosphorus and associated microbial properties under adjacent grassland and forest in New Zealand. For. Ecol. Manage. 177, 539-557.

Chen, C. R., Condron, L. M., Sinaj, S., Davis, M. R., Sherlock, R. R., and Frossard, E. (2003). Effects of plant species on phosphorus availability in a range of grassland soils. Plant Soil 256.1, 115-130. DoI: 10.1023/a: 1026273529177.

Chen, C., Sinaj, S., Condron, L., Frossard, E., Sherlock, R., and Davis, M. (2003). Characterization of phosphorus availability in selected New Zealand grassland soils. Nutri. Cycl. Agroecosyst. 65 (1), 89-100. DoI: 10.1023/A : 1021889207109.

Chen, F. S., Li Xi, G. N., and Zhan, S. X. (2010). Topsoil phosphorus signature in five forest types along an urban-suburban-rural gradient in Nanchang, southern China. Fournal of Forestry Research 21, 39-44.

Chimdi, A., Esala, M., and Ylivainio, K. (2014). Sequential Fractionation Patterns of Soil Phosphorus Collected from Different Land Use Systems of Dire Inchine District, West Shawa Zone, Ethiopia. American-Eurasian Journal of Scientific Research 9, 51-57. 
Chiu, C. Y., Pai, C. W., and Yang, K. L. (2005). Characterization of phosphorus in sub-alpine forest and adjacent grassland soils by chemical extraction and phosphorus-31 nuclear magnetic resonance spectroscopy. Pedobiologia 49, 655-663. DoI: 10.1016/j .pedobi.2005.06.007.

Ciampitti, I. A., Picone, L. I., Rubio, G., and Garcia, F. O. (2011). Pathways of Phosphorous Fraction Dynamics in Field Crop Rotations of the Pampas of Argentina. Soil Sci. Soc. Am. F. 75, 918-926. Dor: 10.2136/sssaj2010. 0361.

Cleveland, C. C., Townsend, A. R., Schmidt, S. K., and Constance, B. C. (2003). Soil microbial dynamics and biogeochemistry in tropical forests and pastures, southwestern Costa Rica. Ecol. Appl. 13, 314-326. DOI: 10.1890/1051-0761(2003)013 [0314:Smdabi]2.0. Co;2.

Compaoré, E., Frossard, E., Sinaj, S., Fardeau, J.-C., and Morel, J.-L. (2003). Influence of Land-Use Management on Isotopically Exchangeable Phosphate in Soils from Burkina Faso. Commun. Soil Sci. Plant Anal. 34.1-2, 201-223. DOI: $10.1081 / \mathrm{css}-120017426$.

Compton, J. E. and Cole, D. W. (2001). Fate and effects of phosphorus additions in soils under N-2-fixing red alder. Biogeochemistry 53, 225-247. DOI: 10.1023/A: 1010646709944.

Condron, L. M., Davis, M. R., Newman, R. H., and Cornforth, I. S. (1996). Influence of conifers on the forms of phosphorus in selected New Zealand grassland soils. Biol. Fertil. Soils 21, 37-42. Dor: 10.1007/Bf00335991.

Couto, R. D., Santos, M. dos, Comin, J. J., Martini, L. C. P., Gatiboni, L. C., Martins, S. R., Belli, P., and Brunetto, G. (2015). Environmental Vulnerability and Phosphorus Fractions of Areas with Pig Slurry Applied to the Soil. $\mathcal{F}$. Environ. Qual. 44, 162-173. Dor: 10.2134/jeq2014.08.0359.

Crews, T. E. (1996). The supply of phosphorus from native, inorganic phosphorus pools in continuously cultivated Mexican agroecosystems. Agric. Ecosyst. Environ. 57, 197-208.

Crews, T. E. and Brookes, P. C. (2014). Changes in soil phosphorus forms through time in perennial versus annual agroecosystems. Agric. Ecosyst. Environ. 184, 168-181. DOI: 10.1016/j . agee.2013.11.022.

Cross, A. F. and Schlesinger, W. H. (2001). Biological and geochemical controls on phosphorus fractions in semiarid soils. Biogeochemistry 52, 155-172. DOI: 10.1023/A : 1006437504494.

De Schrijver, A., Vesterdal, L., Hansen, K., De Frenne, P., Augusto, L., Achat, D. L., Staelens, J., Baeten, L., De Keersmaeker, L., De Neve, S., and Verheyen, K. (2012). Four decades of post-agricultural forest development have caused major redistributions of soil phosphorus fractions. Oecologia 169, 221-234. DoI: 10.1007/s00442011-2185-8.

Delgado, A. and Torrent, J. (1997). Phosphate-rich soils in the European Union: estimating total plant-available phosphorus. Eur. F. Agron. 6.3-4, 205-214. DoI: 10.1016/s1161-0301 (96) 02048-5.

Demaria, P. (2004). Factors controlling phosphate exchangeability and release in agricultural soils. PhD thesis. ETH, Swiss Federal Institute of Technology.

Demaria, P., Sinaj, S., Flisch, R., and Frossard, E. (2013). Soil Properties and Phosphorus Isotopic Exchangeability in Cropped Temperate Soils. Commun. Soil Sci. Plant Anal. 44.1-4, 287-300. Dor: 10.1080/00103624.2013. 741896.

Derry, D. D., Voroney, R. P., and Briceno, J. A. (2005). Long-term effects of short-fallow frijol tapado on soil phosphorus pools in Costa Rica. Agric. Ecosyst. Environ. 110, 91-103. DOI: 10.1016/j . agee. 2005.05.006.

Diekmann, L. O. (2004). Soil nutrient dynamics during shifting cultivation in Campeche, Mexico. Tech. rep., p. 85.

Dieter, D., Elsenbeer, H., and Turner, B. L. (2010). Phosphorus fractionation in lowland tropical rainforest soils in central Panama. Catena 82,118-125. DoI: 10.1016/j.catena.2010.05.010.

Dobermann, A., George, T., and Thevs, N. (2002). Phosphorus fertilizer effects on soil phosphorus pools in acid upland soils. Soil Sci. Soc. Am. F. 66, 652-660.

Dodd, R. J. (2013). Use less, Lose less: Obtaining and maintaining an environmentally and agronomically sustainable farming system with phosphorus. $\mathrm{PhD}$ thesis. Lincoln University.

Dormaar, J. F. and Willms, W. D. (2000). A comparison of soil chemical characteristics in modified rangeland communities. F. Range Manage. 53, 453-458. DoI: 10.2307/4003759.

Duffera, M. and Robarge, W. P. (1999). Soil characteristics and management effects on phosphorus sorption by highland plateau soils of Ethiopia. Soil Sci. Soc. Am. F. 63, 1455-1462.

Elpat'evskii, P. V. (1998). Stores and dynamics of available phosphorus in brown forest soils of southern primorye forests in the Far East. Eurasian Soil Sci. 31, 54-60.

Esberg, C., Toit, B. du, Olsson, R., Ilstedt, U., and Giesler, R. (2010). Microbial responses to P addition in six South African forest soils. Plant Soil 329, 209-225. Dor: 10.1007/s11104-009-0146-3.

Fabre, A., Pinay, G., and Ruffinoni, C. (1996). Seasonal changes in inorganic and organic phosphorus in the soil of a riparian forest. Biogeochemistry 35, 419-432. DOI: 10.1007/Bf02183034.

Fan, J., Wang, J. Y., Hu, X. F., and Chen, F. S. (2014). Seasonal dynamics of soil nitrogen availability and phosphorus fractions under urban forest remnants of different vegetation communities in Southern China. Urban For. Urban Greening 13, 576-585. DOI: 10.1016/j .ufug.2014.03.002. 
Fardeau, J. C., Morel, C., and Jappe, J. (1985). Cinétique d'échange des ions phosphate dans les systèmes sol-solution. Vérification expérimentale de l'équation théorique. In: C.R. Acad. Sci. Paris, $t$ 300, série III 8, 371-376.

Fardeau, J. (1993). Le phosphore biodisponible du sol. Un système pluricompartimental à structure mamellaire. Agronomie 1, 1-13.

Fardeau, J., Morel, C., and Boniface, R. (1991). Cinétiques de transfert des ions phosphate du sol vers la solution du sol : paramètres caractéristiques. Agronomie 11.9, 787-797. DoI: 10.1051/agro: 19910909.

Finzi, A. C. (2009). Decades of atmospheric deposition have not resulted in widespread phosphorus limitation or saturation of tree demand for nitrogen in southern New England. Biogeochemistry 92, 217-229. DOI: 10.1007/s10533-009-9286-z.

Frizano, J., Johnson, A. H., Vann, D. R., and Scatena, F. N. (2002). Soil phosphorus fractionation during forest development on landslide scars in the Luquillo Mountains, Puerto Rico. Biotropica 34, 17-26.

Frizano, J., Vann, D. R., Johnson, A. H., Johnson, C. M., Vieira, I. C. G., and Zarin, D. J. (2003). Labile phosphorus in soils of forest fallows and primary forest in the Bragantina region, Brazil. Biotropica 35, 2-11.

Frossard, E., Bolomey, S., Flura, T., and Sinaj, S. (2005). Phosphore du sol et stratégie de fertilisation. Le cas du lac de Baldegg. In: Documents environnement. Vol. 206.

Frossard, E., López-Hernández, D., and Brossard, M. (1996). Can isotopic exchange kinetics give valuable information on the rate of mineralization of organic phosphorus in soils? Soil Biol. Biochem. 28.7, 857-864. DOI: 10.1016/0038-0717(96)00063-6.

Frossard, E., Morel, J. L., Fardeau, J. C., and Brossard, M. (1994). Soil Isotopically Exchangeable Phosphorus: A Comparison between E and L Values. Soil Sci. Soc. Am. J. 58.3, 846-851. DoI: 10 . 2136 / sssaj 1994 . $03615995005800030031 x$.

Frossard, E., Stewart, J. W. B., and St-Arnaud, R. J. (1989). Distribution and mobility of phosphorus in grassland and forest soils of Saskatchewan. Can. F. Soil Sci. 69.2, 401-416. Dor: 10.4141/cj ss89-040.

Frossard, E., Achat, D., Bernasconi, S., Bünemann, E., Fardeau, J.-C., Jansa, J., Morel, C., Rabeharisoa, L., Randriamanantsoa, L., Sinaj, S., Tamburini, F., and Oberson, A. (2011). The Use of Tracers to Investigate Phosphate Cycling in Soil-Plant Systems. In: Phosphorus in Action. Vol. 100, 59-91. DOI: 10.1007/978-3-642-152719_3.

Gabbasova, I. M., Sirayeva, E. Z., Kol'tsova, G. A., and Khakimova, G. A. (1993). Content and composition of organic phosphates in the soils of Bashkiria. Eurasian Soil Sci. 25, 36-48.

Galang, M. A., Markewitz, D., and Morris, L. A. (2010). Soil phosphorus transformations under forest burning and laboratory heat treatments. Geoderma 155, 401-408. DoI: 10.1016/j .geoderma.2009.12.026.

Gallet, A., Flisch, R., Ryser, J.-P., Frossard, E., and Sinaj, S. (2003). Effect of phosphate fertilization on crop yield and soil phosphorus status. f. Plant Nutr. Soil Sci. 166.5, 568-578. DOI: 10.1002/jpln. 200321081.

Garcia-Montiel, D. C., Neill, C., Melillo, J., Thomas, S., Steudler, P. A., and Cerri, C. C. (2000). Soil phosphorus transformations following forest clearing for pasture in the Brazilian Amazon. Soil Sci. Soc. Am. F. 64, 17921804.

Gazizullin, A. K. and Sabirov, A. T. (1991). Iron oxides in major types of Forest soils of the Middle Volga Region. Soviet Soil Science 23, 84-102.

Giardina, C. P., Sanford, R. L., and Dockersmith, I. C. (2000). Changes in soil phosphorus and nitrogen during slash-and-burn clearing of a dry tropical forest. Soil Sci. Soc. Am. F. 64, 399-405.

Gichangi, E. M., Mnkeni, P. N. S., and Brookes, P. C. (2009). Effects of goat manure and inorganic phosphate addition on soil inorganic and microbial biomass phosphorus fractions under laboratory incubation conditions. Soil Sci. Plant Nutr. 55, 764-771. DoI: 10.1111/j .1747-0765.2009.00415 .x.

Gleason, S. M., Read, J., Ares, A., and Metcalfe, D. J. (2009). Phosphorus economics of tropical rainforest species and stands across soil contrasts in Queensland, Australia: understanding the effects of soil specialization and trait plasticity. Funct. Ecol. 23, 1157-1166. DoI: 10.1111/j.1365-2435.2009.01575.x.

Gorbachev, V. N. and Popova, E. P. (1984). Characteristics of soil formation on loesslike loams in the southern taiga of central Siberia. Soviet Soil Science 16, 12-18.

Gressel, N., Mccoll, J. G., Preston, C. M., Newman, R. H., and Powers, R. F. (1996). Linkages between phosphorus transformations and carbon decomposition in a forest soil. Biogeochemistry 33, 97-123. DOI: 10 . 1007 / Bf02181034.

Guardini, R., Comin, J. J., Schmitt, D. E., Tiecher, T., Bender, M. A., Santos, D. R. dos, Mezzari, C. P., Oliveira, B. S., Gatiboni, L. C., and Brunetto, G. (2012). Accumulation of phosphorus fractions in typic Hapludalf soil after long-term application of pig slurry and deep pig litter in a no-tillage system. Nutri. Cycl. Agroecosyst. 93, 215-225. DOI: $10.1007 /$ s10705-012-9511-3.

Gundale, M. J., Sutherland, S., and DeLuca, T. H. (2008). Fire, native species, and soil resource interactions influence the spatio-temporal invasion pattern of Bromus tectorum. Ecography 31, 201-210. Dor: 10.1111/j.09067590.2008.5303.x. 
Haefele, S. M., Wopereis, M. C. S., Schloebohm, A. M., and Wiechmann, H. (2004). Long-term fertility experiments for irrigated rice in the West African Sahel: effect on soil characteristics. Field Crops Research 85, 61-77. DOI: 10.1016/S0378-4290(03)00153-9.

Hamon, R. E. and McLaughlin, M. J. (2002). Interferences in the determination of isotopically exchangeable P in soils and a method to minimise them. Aust. F. Soil Res. 40.8, 1383-1397. DoI: 10.1071/sr02045.

Hartono, A., Funakawa, S., and Kosaki, T. (2006). Transformation of added phosphorus to acid upland soils with different soil properties in Indonesia. Soil Sci. Plant Nutr. 52, 734-744. DOI: 10.1111/j .1747-0765.2006. $00087 . x$.

Hashimoto, Y. and Watanabe, Y. (2014). Combined applications of chemical fractionation, solution P-31-NMR and $\mathrm{P}$ K-edge XANES to determine phosphorus speciation in soils formed on serpentine landscapes. Geoderma 230, 143-150. DOI: 10.1016/j.geoderma. 2014.04.001.

Heinrich, P. A. and Patrick, J. W. (1985). Phosphorus Acquisition in the Soil Root-System of Eucalyptus-Pilularis Sm Seedlings .1. Characteristics of the Soil System. Aust. F. Soil Res. 23, 223-236. DoI: 10.1071/Sr9850223.

Hernández, G., Cuenca, G., and García, A. (2000). Behaviour of arbuscular-mycorrhizal fungi on Vigna luteola growth and its effect on the exchangeable ( $32 \mathrm{P}$ ) phosphorus of soil. Biol. Fertil. Soils 31.3-4, 232-236. DOI: $10.1007 / \mathrm{s} 003740050650$.

Hu, X. F., Chen, F. S., Nagle, G., Fang, Y. T., and Yu, M. Q. (2011). Soil phosphorus fractions and tree phosphorus resorption in pine forests along an urban-to-rural gradient in Nanchang, China. Plant Soil 346, 97-106. DOI: 10.1007/s11104-011-0799-6.

Ilstedt, U., Giesler, R., Nordgren, A., and Malmer, A. (2003). Changes in soil chemical and microbial properties after a wildfire in a tropical rainforest in Sabah, Malaysia. Soil Biol. Biochem. 35, 1071-1078. DoI: 10.1016/S00380717 (03) 00152-4.

Imai, N., Kitayama, K., and Titin, J. (2010). Distribution of phosphorus in an above-to-below-ground profile in a Bornean tropical rain forest. F. Trop. Ecol. 26, 627-636. DoI: 10.1017/S0266467410000350.

Izquierdo, J. E., Houlton, B. Z., and Huysen, T. L. van (2013). Evidence for progressive phosphorus limitation over long-term ecosystem development: Examination of a biogeochemical paradigm. Plant Soil 367, 135-147. DOI: 10.1007/s11104-013-1683-3.

Keller, M., Oberson, A., Annaheim, K. E., Tamburini, F., Mader, P., Mayer, J., Frossard, E., and Bunemann, E. K. (2012). Phosphorus forms and enzymatic hydrolyzability of organic phosphorus in soils after 30 years of organic and conventional farming. F. Plant Nutr. Soil Sci. 175, 385-393. Dor: 10.1002/jpln. 201100177.

Khan, K. S. and Joergensen, R. G. (2012). Relationships between P fractions and the microbial biomass in soils under different land use management. Geoderma 173, 274-281. DOI: 10.1016/j .geoderma.2011.12.022.

Kitayama, K., Aiba, S. I., Takyu, M., Majalap, N., and Wagai, R. (2004). Soil phosphorus fractionation and phosphorususe efficiency of a Bornean tropical montane rain forest during soil aging with podozolization. Ecosystems 7 , 259-274. DOI: $10.1007 /$ s10021-003-0229-6.

Kolahchi, Z. and Jalali, M. (2012). Speciation of Phosphorus in Phosphorus-Amended and Leached Calcareous Soils Using Chemical Fractionation. Pol. F. Environ. Stud. 21, 395-400.

Kolawole, G. O., Tijani-Eniola, H., and Tian, G. (2004). Phosphorus fractions in fallow systems of West Africa: Effect of residue management. Plant Soil 263, 113-120. DoI: 10.1023/B:P1so.0000047730.58844.B5.

Kristiansen, S. M., Amelung, W., and Zech, W. (2001). Phosphorus forms as affected by abandoned anthills (Formica polyctena Forster) in forest soils: sequential extraction and liquid-state P-31-NMR spectroscopy. F. Plant Nutr. Soil Sci. 164, 49-55. DoI: 10.1002/1522-2624(200102) 164:1<49 : : Aid-Jpln49>3 . 0 . Co;2-X.

Krivonosova, G. M. and Basevich, T. V. (1980). Content and forms of organic phosphates in the soils of the steppe zone of the Ukraine [USSR]. Soviet Soil Science 12, 290-294.

Kuczak, C. N., Fernandes, E. C. M., Lehmann, J., Rondon, M. A., and Luizao, F. J. (2006). Inorganic and organic phosphorus pools in earthworm casts (Glossoscolecidae) and a Brazilian rainforest Oxisol. Soil Biol. Biochem. 38, 553-560. DoI: 10.1016/j.soilbio.2005.06.007.

Kunito, T., Tsunekawa, M., Yoshida, S., Park, H. D., Toda, H., Nagaoka, K., and Saeki, K. (2012). Soil Properties Affecting Phosphorus Forms and Phosphatase Activities in Japanese Forest Soils: Soil Microorganisms May Be Limited by Phosphorus. Soil Sci. 177, 39-46. DoI: 10.1097/SS . 0b013e3182378153.

Kvarnstrom, E., Morel, C., Fardeau, J.-C., Morel, J.-L., and Esa, S. (2000). Changes in the phosphorus availability of a chemically precipitated urban sewage sludge as a result of different dewatering processes. Waste Manage. Res. 18.3, 249-258. DOI: 10.1177/0734242x0001800306.

Lan, Z. M., Lin, X. J., Wang, F., Zhang, H., and Chen, C. R. (2012). Phosphorus availability and rice grain yield in a paddy soil in response to long-term fertilization. Biol. Fertil. Soils 48, 579-588. Dor: 10.1007/s00374-0110650-5.

Lee, D., Han, X. G., and Jordan, C. F. (1990). Soil-Phosphorus Fractions, Aluminum, and Water-Retention as Affected by Microbial Activity in an Ultisol. Plant Soil 121, 125-136. DOI: 10.1007/Bf00013105. 
Lehmann, J., Gunther, D., Mota, M. S. da, Almeida, M. P. de, Zech, W., and Kaiser, K. (2001). Inorganic and organic soil phosphorus and sulfur pools in an Amazonian multistrata agroforestry system. Agrofor. Syst. 53, 113-124. DOI: $10.1023 / \mathrm{A}: 1013364201542$.

Levy, E. T. and Schlesinger, W. H. (1999). A comparison of fractionation methods for forms of phosphorus in soils. Biogeochemistry 47, 25-38. DOI: 10.1023/A : 1006105420235.

Li, L., Liang, X. Q., Ye, Y. S., Zhao, Y., Zhang, Y. X., Jin, Y., Yuan, J. L., and Chen, Y. X. (2015). Effects of repeated swine manure applications on legacy phosphorus and phosphomonoesterase activities in a paddy soil. Biol. Fertil. Soils 51, 167-181. DoI: 10.1007/s00374-014-0956-1.

Li, Y. F., Luo, A. C., Wei, X. H., and Yao, X. G. (2008). Changes in Phosphorus Fractions, pH, and Phosphatase Activity in Rhizosphere of Two Rice Genotypes. Pedosphere 18, 785-794. DoI: 10.1016/S1002-0160 (08)60074-0.

Li, Y. Y., Yang, R., Gao, R., Wei, H. A., Chen, A. L., and Li, Y. (2015). Effects of long-term phosphorus fertilization and straw incorporation on phosphorus fractions in subtropical paddy soil. Fournal of Integrative Agriculture 14, 365-373. DOI: 10 . 1016/S2095-3119(13) 60684-X.

Liu, Q., Loganathan, P., Hedley, M. J., and Skinner, M. F. (2004). The mobilisation and fate of soil and rock phosphate in the rhizosphere of ectomycorrhizal Pinus radiata seedlings in an Allophanic soil. Plant Soil 264, 219-229. DOI: $10.1023 / \mathrm{B}$ : Plso.0000047758.77661.57.

Lopez-Hernandez, D., Brossard, M., and Frossard, E. (1998). P-Isotopic exchange values in relation to Po mineralisation in soils with very low P-sorbing capacities. Soil Biol. Biochem. 30.13, 1663-1670. DoI: 10.1016/s00380717 (97) 00255-1.

Magid, J. (1993). Vegetation Effects on Phosphorus Fractions in Set-Aside Soils. Plant Soil 149, 111-119. Dor: 10.1007/Bf00010768.

Makarov, M. I., Malysheva, T. I., Vladychenskii, A. S., and Zech, W. (2002). Phosphorus compounds in primitive soils on mantle loam under various phytocenoses. Eurasian Soil Sci. 35, 924-933.

Makarov, M. I., Volkov, A. V., Malysheva, T. I., and Onipchenko, V. G. (2001). Phosphorus, nitrogen, and carbon in the soils of subalpine and alpine altitudinal belts of the Teberda Nature Reserve. Eurasian Soil Sci. 34, 52-60.

Malik, M. A., Khan, K. S., Fayyaz-ul-Hassan, and Umair, A. (2014). Dynamics of Phosphorus Pools in Subtropical Alkaline Soils. International fournal of Agriculture and Biology 16, 293-299.

Markewitz, D., Figueiredo, R. D., Carvalho, C. J. R. de, and Davidson, E. A. (2012). Soil and tree response to P fertilization in a secondary tropical forest supported by an Oxisol. Biol. Fertil. Soils 48, 665-678. DoI: 10.1007/s00374-011-0659-9.

McGrath, D. A., Duryea, M. L., and Cropper, W. P. (2001). Soil phosphorus availability and fine root proliferation in Amazonian agroforests 6 years following forest conversion. Agric. Ecosyst. Environ. 83, 271-284. DOI: 10.1016/S0167-8809(00)00176-6.

McGroddy, M. E., Silver, W. L., Oliveira, R. C. de, Mello, W. Z. de, and Keller, M. (2008). Retention of phosphorus in highly weathered soils under a lowland Amazonian forest ecosystem. Fournal of Geophysical ResearchBiogeosciences 113. DOI: ArtnG0401210.1029/2008jg000756.

Mckenzie, R. H., Stewart, J. W. B., Dormaar, J. F., and Schaalje, G. B. (1992a). Long-term crop-rotation and fertilizer effects on phosphorus transformations .1. In a chernozemic Soil. Can. F. Soil Sci. 72, 569-579.

Mckenzie, R. H., Stewart, J. W. B., Dormaar, J. F., and Schaalje, G. B. (1992b). Long-term crop-rotation and fertilizer effects on phosphorus transformations .2. In a luvisolic Soil. Can. F. Soil Sci. 72, 581-589.

Meason, D. F., Idol, T. W., Friday, J. B., and Scowcroft, P. G. (2009). Effects of fertilisation on phosphorus pools in the volcanic soil of a managed tropical forest. For. Ecol. Manage. 258, 2199-2206. Dor: 10.1016/j.foreco. 2009.04 .001$.

Menzies, N. W., Skilton, J. A., and Guppy, C. N. (1999). Phosphorus storage on effluent irrigated land. F. Environ. Qual. 28, 750-754.

Messiga, A. J., Ziadi, N., Plénet, D., Parent, L.-E., and Morel, C. (2010). Long-term changes in soil phosphorus status related to $\mathrm{P}$ budgets under maize monoculture and mineral $\mathrm{P}$ fertilization. Soil Use and Management 26.3, 354-364. DOI: $10.1111 / \mathrm{j} .1475-2743.2010 .00287 . \mathrm{x}$.

Messiga, A. J., Ziadi, N., Bélanger, G., and Morel, C. (2012). Process-based mass-balance modeling of soil phosphorus availability in a grassland fertilized with N and P. Nutri. Cycl. Agroecosyst. 92.3, 273-287. Dor: $10.1007 /$ s10705-012-9489-x.

Messiga, A. J., Ziadi, N., Mollier, A., Parent, L.-E., Schneider, A., and Morel, C. (2015). Process-based mass-balance modeling of soil phosphorus availability: Testing different scenarios in a long-term maize monoculture. Geoderma 243-244, 41-49. DoI: 10.1016/j.geoderma.2014.12.009.

Miller, A. J., Schuur, E. A. G., and Chadwick, O. A. (2001). Redox control of phosphorus pools in Hawaiian montane forest soils. Geoderma 102, 219-237. DoI: 10.1016/S0016-7061(01)00016-7. 
Mirabello, M. J., Yavitt, J. B., Garcia, M., Harms, K. E., Turner, B. L., and Wright, S. J. (2013). Soil phosphorus responses to chronic nutrient fertilisation and seasonal drought in a humid lowland forest, Panama. Soil Res. 51, 215-221. DOI: 10.1071/SR12188.

Morel, C. (2001). The effects of soil solution P and time on the transfer of P ions in soils from the IMPHOS European Network. In: The effect of phosphate fertilizer management strategies on soil phosphorus status and crop yields in some European countries, 103-102.

Morel, C., Cachot, C., Martinez, J., Peu, P., Elsass, F., Robert, M., and Fardeau, J. (2004). Évolution sur 12 ans de la solubilité, mobilité et lixiviation du phosphate dans un sol ayant massivement reçu du lisier. Étude et Gestion des sols 11.4 .

Morel, C. and Hinsinger, P. (1999). Root-induced mmodification of the exchange of phosphate ion between soil solution and soil solid phase. Plant Soil 211.1, 103-110. DoI: 10.1023/a:1004485432261.

Morel, C., Tiessen, H., Moir, J. O., and Stewart, J. W. B. (1994). Phosphorus Transformations and Availability under Cropping and Fertilization Assessed by Isotopic Exchange. Soil Sci. Soc. Am. 7. 58.5, 1439-1445. DOI: $10.2136 /$ sssaj 1994.03615995005800050023x.

Morel, C., Tunney, H., Plénet, D., and Pellerin, S. (2000). Transfer of Phosphate Ions between Soil and Solution: Perspectives in Soil Testing. F. Environ. Qual. 29.1, 50-59. Dor: 10.2134/jeq2000.00472425002900010007x.

Mortala, N. A. (2013). Comportamiento de las formas de fósforo en un Ultisol con diferentes manejos de implantación forestal. Tech. rep., p. 116.

Neufeldt, H., Silva, J. E. da, Ayarza, M. A., and Zech, W. (2000). Land-use effects on phosphorus fractions in Cerrado oxisols. Biol. Fertil. Soils 31, 30-37. DOI: 10.1007/s003740050620.

Newbery, D. M., Alexander, I. J., and Rother, J. A. (1997). Phosphorus dynamics in a lowland African rain forest: The influence of ectomycorrhizal trees. Ecol. Monogr. 67, 367-409.

Nguyen, H., Schoenau, J. J., Van Rees, K., Nguyen, D., and Qian, R. (2001). Long-term nitrogen, phosphorus and potassium fertilization of cassava influences soil chemical properties in North Vietnam. Can. F. Soil Sci. 81, 481-488.

Nikonov, V. V. (1979). Characteristics of soil formation in the northern taiga spruce biogeocenoses of the Kola peninsula. Soviet Soil Science 11, 501-511.

Oberson, A., Fardeau, J. C., Besson, J. M., and Sticher, H. (1993a). Soil phosphorus dynamics in cropping systems managed according to conventional and biological agricultural methods. Biol. Fertil. Soils 16.2, 111-117. DoI: $10.1007 / \mathrm{bf} 00369411$.

Oberson, A., Fardeau, J. C., Besson, J. M., and Sticher, H. (1993b). Soil-Phosphorus Dynamics in Cropping Systems Managed According to Conventional and Biological Agricultural Methods. Biol. Fertil. Soils 16, 111-117. DoI: $10.1007 / \mathrm{Bf} 00369411$.

Oberson, A., Friesen, D., Tiessen, H., Morel, C., and Stahel, W. (1999). Phosphorus status and cycling in native savanna and improved pastures on an acid low-P Colombian Oxisol. Nutri. Cycl. Agroecosyst. 55.1, 77-88. DOI: 10.1023/a: 1009813008445 .

Oehl, F. (1999). Microbially mediated phosphorus transformation processes in cultivated soils. PhD thesis. ETH, Swiss Federal Institute of Technology.

Oehl, F., Frossard, E., Fliessbach, A., Dubois, D., and Oberson, A. (2004). Basal organic phosphorus mineralization in soils under different farming systems. Soil Biol. Biochem. 36.4, 667-675. DOI: 10.1016/j . soilbio.2003. 12.010.

Ohalloran, I. P., Stewart, J. W. B., and Dejong, E. (1987). Changes in P-Forms and Availability as Influenced by Management-Practices. Plant Soil 100, 113-126. DoI: 10.1007/Bf02370935.

Otabbong, E., Persson, J., Iakimenko, O., and Sadovnikova, L. (1997). The Ultuna long-term soil organic matter experiment .2. Phosphorus status and distribution in soils. Plant Soil 195, 17-23. DOI: 10.1023/A : 1004276732679.

Owusu-Bennoah, E. and Acquaye, D. K. (1996). Greenhouse evaluation of agronomic potential of different sources of phosphate fertilizer in a typical concretionary soil of northern Ghana. Fertil. Res. 44, 101-106.

Paniagua, A., Mazzarino, M. J., Kass, D., Szott, L., and Fernandez, C. (1995). Soil-Phosphorus Fractions under 5 Tropical Agroecosystems on a Volcanic Soil. Aust. f. Soil Res. 33, 311-320. Dor: 10.1071/Sr9950311.

Pare, D. and Bernier, B. (1989). Origin of the Phosphorus Deficiency Observed in Declining Sugar Maple Stands in the Quebec Appalachians. Can. F. For. Res. 19, 24-34. DoI: 10.1139/X89-004.

Patzold, S., Hejcman, M., Barej, J., and Schellberg, J. (2013). Soil phosphorus fractions after seven decades of fertilizer application in the Rengen Grassland Experiment. F. Plant Nutr. Soil Sci. 176, 910-920. Dor: 10.1002/ jpln. 201300152.

Pavinato, P. S., Merlin, A., and Rosolem, C. A. (2009). Phosphorus fractions in Brazilian Cerrado soils as affected by tillage. Soil Tillage Res. 105, 149-155. Dor: 10.1016/j.still.2009.07.001. 
Perroni, Y., Garcia-Oliva, F., Tapia-Torres, Y., and Souza, V. (2014). Relationship between soil P fractions and microbial biomass in an oligotrophic grassland-desert scrub system. Ecol. Res. 29, 463-472. DOI: 10.1007/ s11284-014-1138-1.

Pinochet, D., Epple, G., and MacDonald, R. (2001). Organic and inorganic phosphorus fractions in a soil transect of volcanic and metamorphic origin. R.C. Suelo Nutr. Veg. 1, 58-69.

Pizzeghello, D., Berti, A., Nardi, S., and Morari, F. (2011). Phosphorus forms and P-sorption properties in three alkaline soils after long-term mineral and manure applications in north-eastern Italy. Agric. Ecosyst. Environ. 141.1-2, 58-66. DOI: 10.1016/j.agee.2011.02.011.

Quesada, C. A., Lloyd, J., Schwarz, M., Patino, S., Baker, T. R., Czimczik, C., Fyllas, N. M., Martinelli, L., Nardoto, G. B., Schmerler, J., Santos, A. J. B., Hodnett, M. G., Herrera, R., Luizao, F. J., Arneth, A., Lloyd, G., Dezzeo, N., Hilke, I., Kuhlmann, I., Raessler, M., Brand, W. A., Geilmann, H., Moraes, J. O., Carvalho, F. P., Araujo, R. N., Chaves, J. E., Cruz, O. F., Pimentel, T. P., and Paiva, R. (2010). Variations in chemical and physical properties of Amazon forest soils in relation to their genesis. Biogeosciences 7, 1515-1541. DoI: 10.5194/bg-7-1515-2010.

Quintero, C. E., Gutierrez-Boem, F. H., Befani, M. R., and Boschetti, N. G. (2007). Effects of soil flooding on P transformations in soils of the Mesopotamia region, Argentina. F. Plant Nutr. Soil Sci. 170, 500-505. DOI: 10.1002/jpln.200625015.

Rabeharisoa, R. (2004). Gestion de la fertilité et de la fertilisation phosphatée des sols ferrallitiques des hautes terres de Madagascar. PhD thesis. Université d'Antanarivo.

Randriamanantsoa, L., Frossard, E., Oberson, A., and Bünemann, E. K. (2015). Gross organic phosphorus mineralization rates can be assessed in a Ferralsol using an isotopic dilution method. Geoderma 257-258, 86-93. DOI: $10.1016 / \mathrm{j}$.geoderma. 2015.01.003.

Randriamanantsoa, L., Morel, C., Rabeharisoa, L., Douzet, J.-M., Jansa, J., and Frossard, E. (2013). Can the isotopic exchange kinetic method be used in soils with a very low water extractable phosphate content and a high sorbing capacity for phosphate ions? Geoderma 200-201, 120-129. DoI: 10.1016/j . geoderma. 2013.01.019.

Reddy, D. D., Rao, S. A., and Singh, M. (2005). Changes in P fractions and sorption in an Alfisol following crop residues application. F. Plant Nutr. Soil Sci. 168, 241-247. DoI: 10.1002/jpln. 200421444.

Reddy, K. S., Rao, A. S., and Takkar, P. N. (1996). Transformation of fertilizer P in a Vertisol amended with farmyard manure. Biol. Fertil. Soils 22, 279-282. DoI: 10.1007/s003740050111.

Redel, Y. D., Rubio, R., Rouanet, J. L., and Borie, F. (2007). Phosphorus bioavailability affected by tillage and crop rotation on a Chilean volcanic derived Ultisol. Geoderma 139, 388-396. DoI: 10.1016/j . geoderma. 2007. 02.018.

Redel, Y., Rubio, R., Godoy, R., and Borie, F. (2008). Phosphorus fractions and phosphatase activity in an Andisol under different forest ecosystems. Geoderma 145, 216-221. Dor: 10.1016/j . geoderma. 2008.03.007.

Richter, D. D., Allen, H. L., Li, J. W., Markewitz, D., and Raikes, J. (2006). Bioavailability of slowly cycling soil phosphorus: major restructuring of soil P fractions over four decades in an aggrading forest. Oecologia 150, 259-271. DOI: $10.1007 / \mathrm{s} 00442-006-0510-4$.

Roberts, T. L., Stewart, J. W. B., and Bettany, J. R. (1985). The Influence of Topography on the Distribution of Organic and Inorganic Soil-Phosphorus across a Narrow Environmental Gradient. Can. F. Soil Sci. 65, 651-665.

Rose, T. J., Hardiputra, B., and Rengel, Z. (2010). Wheat, canola and grain legume access to soil phosphorus fractions differs in soils with contrasting phosphorus dynamics. Plant Soil 326, 159-170. DOI: 10.1007/s11104-009$9990-4$.

Rubio, G., Faggioli, V., Scheiner, J. D., and Gutierrez-Boem, F. H. (2012). Rhizosphere phosphorus depletion by three crops differing in their phosphorus critical levels. F. Plant Nutr. Soil Sci. 175. DOI: 10.1002/jpln. 201200307.

Ruckamp, D., Amelung, W., Theisz, N., Bandeira, A. G., and Martius, C. (2010). Phosphorus forms in Brazilian termite nests and soils: Relevance of feeding guild and ecosystems. Geoderma 155, 269-279. DOI: 10.1016/j . geoderma.2009.12.010.

Saa, A., Trasar-Cepeda, M. C., and Carballas, T. (1998). Soil P status and phosphomonoesterase activity of recently burnt and unburnt soil following laboratory incubation. Soil Biol. Biochem. 30, 419-428. DOI: 10.1016/S00380717 (97) 00120-X.

Salcedo, I. H., Bertino, F., and Sampaio, E. V. S. B. (1991). Reactivity of Phosphorus in Northeastern Brazilian Soils Assessed by Isotopic Dilution. Soil Sci. Soc. Am. J. 55.1, 140-145. DOI: 10 . 2136 / sssaj 1991. $03615995005500010025 x$.

Saltali, K., Kilic, K., and Kocyigit, R. (2007). Changes in sequentially extracted phosphorus fractions in adjacent arable and grassland ecosystems. Arid Land Research and Management 21, 81-89. DOI: 10 . 1080 / 15324980601074602.

Sattell, R. R. and Morris, R. A. (1992). Phosphorus Fractions and Availability in Sri-Lankan Alfisols. Soil Sci. Soc. Am. F. 56, 1510-1515. 
Satti, P., Mazzarino, M. J., Roselli, L., and Crego, P. (2007). Factors affecting soil P dynamics in temperate volcanic soils of southern Argentina. Geoderma 139, 229-240. DoI: 10.1016/j.geoderma. 2007.02.005.

Scharer, M. (2003). The influence of processes controlling phosphorus availability on phosphorus losses in grassland soils. PhD thesis. ETH, Swiss Federal Institute of Technology.

Schoenau, J. J., Stewart, J. W. B., and Bettany, J. R. (1989). Forms and Cycling of Phosphorus in Prairie and Boreal Forest Soils. Biogeochemistry 8, 223-237.

Scott, D. A. and Bliss, C. M. (2012). Phosphorus Fertilizer Rate, Soil P Availability, and Long-Term Growth Response in a Loblolly Pine Plantation on a Weathered Ultisol. Forests 3, 1071-1085. Dor: 10.3390/f3041071.

Scott, J. T. and Condron, L. M. (2003). Dynamics and availability of phosphorus in the rhizosphere of a temperate silvopastoral system. Biol. Fertil. Soils 39, 65-73. DOI: 10.1007/s00374-003-0678-2.

Sharpley, A. N., Jones, C. A., Gray, C., Cole, C. V., Tiessen, H., and Holzhey, C. S. (1985). A detailed phosphorus characterization of seventy-eight soils. Tech. rep., p. 30.

Sharpley, A. N., McDowell, R. W., and Kleinman, P. J. A. (2004). Amounts, forms, and solubility of phosphorus in soils receiving manure. Soil Sci. Soc. Am. J. 68, 2048-2057.

Sheklabadi, M., Mahmoudzadeh, H., Mahboubi, A. A., Gharabaghi, B., and Ahrens, B. (2014). Land use effects on phosphorus sequestration in soil aggregates in western Iran. Environ. Monit. Assess. 186, 6493-6503. DOI: 10.1007/s10661-014-3869-4.

Shiels, A. B. and Sanford, R. L. (2001). Soil nutrient differences between two krummholz-form tree species and adjacent alpine tundra. Geoderma 102, 205-217. DoI: 10.1016/S0016-7061(01)00015-5.

Sinaj, S., Frossard, E., and Fardeau, J. C. (1997). Isotopically Exchangeable Phosphate in Size Fractionated and Unfractionated Soils. Soil Sci. Soc. Am. F. 61.5, 1413-1417. DoI: 10.2136/sssaj1997.03615995006100050019x.

Singh, M., Reddy, K. S., Singh, V. P., and Rupa, T. R. (2007). Phosphorus availability to rice (Oriza sativa L.)-wheat (Triticum estivum L.) in a Vertisol after eight years of inorganic and organic fertilizer additions. Bioresour. Technol. 98, 1474-1481. DOI: 10.1016/j.biortech.2006.02.045.

Slazak, A., Freese, D., Matos, E. D., and Huttl, R. F. (2010). Soil organic phosphorus fraction in pine-oak forest stands in Northeastern Germany. Geoderma 158, 156-162. DoI: 10.1016/j . geoderma. 2010.04.023.

Soinne, H., Raty, M., and Hartikainen, H. (2010). Effect of air-drying on phosphorus fractions in clay soil. 7 . Plant Nutr. Soil Sci. 173, 332-336. DoI: 10.1002/jpln. 200900225.

Solomon, D. and Lehmann, J. (2000). Loss of phosphorus from soil in semi-arid northern Tanzania as a result of cropping: evidence from sequential extraction and ${ }^{31} \mathrm{P}-\mathrm{NMR}$ spectroscopy. Eur. F. Soil Sci. 51, 699-708.

Solomon, D., Lehmann, J., Mamo, T., Fritzsche, F., and Zech, W. (2002). Phosphorus forms and dynamics as influenced by land use changes in the sub-humid Ethiopian highlands. Geoderma 105, 21-48.

Spears, J. D. H., Lajtha, K., Caldwell, B. A., Pennington, S. B., and Vanderbilt, K. (2001). Species effects of Ceanothus velutinus versus Pseudotsuga menziesii, Douglas-fir, on soil phosphorus and nitrogen properties in the Oregon cascades. For. Ecol. Manage. 149, 205-216. DoI: 10.1016/S0378-1127 (00)00555-7.

Spohn, M., Ermak, A., and Kuzyakov, Y. (2013). Microbial gross organic phosphorus mineralization can be stimulated by root exudates - A 33P isotopic dilution study. Soil Biol. Biochem. 65, 254-263. Dor: 10.1016/j . soilbio.2013.05.028.

Stroia, C., Morel, C., and Jouany, C. (2007). Dynamics of diffusive soil phosphorus in two grassland experiments determined both in field and laboratory conditions. Agric. Ecosyst. Environ. 119.1-2, 60-74. DoI: 10.1016/j . agee.2006.06.007.

Su, J., Wang, H., Kimberley, M. O., Beecroft, K., Magesan, G. N., and Hu, C. (2007). Fractionation and mobility of phosphorus in a sandy forest soil amended with biosolids. Environ. Sci. Pollut. Res. 14, 529-535. DOI: 10.1065/espr2007.08.443.

Suarez, E. R., Pelletier, D. M., Fahey, T. J., Groffman, P. M., Bohlen, P. J., and Fisk, M. C. (2003). Effects of exotic earthworms on soil phosphorus cycling in two broadleaf temperate forests. Ecosystems 7, 28-44. DOI: 10.1007/s10021-003-0128-x.

Sugihara, S., Funakawa, S., Nishigaki, T., Kilasara, M., and Kosaki, T. (2012). Dynamics of fractionated P and P budget in soil under different land management in two Tanzanian croplands with contrasting soil textures. Agric. Ecosyst. Environ. 162, 101-107. DOI: 10.1016/j .agee.2012.07.019.

Sugihara, S., Shibata, M., Mvondo Ze, A. D., Araki, S., and Funakawa, S. (2014). Effect of vegetation on soil C, N, P and other minerals in Oxisols at the forest-savanna transition zone of central Africa. Soil Sci. Plant Nutr. 60, 45-59. DOI: 10.1080/00380768.2013.866523.

Sui, Y. B., Thompson, M. L., and Shang, C. (1999). Fractionation of phosphorus in a mollisol amended with biosolids. Soil Sci. Soc. Am. J. 63, 1174-1180.

Sun, H. Y., Wu, Y. H., Yu, D., and Zhou, J. (2013). Altitudinal Gradient of Microbial Biomass Phosphorus and Its Relationship with Microbial Biomass Carbon, Nitrogen, and Rhizosphere Soil Phosphorus on the Eastern Slope of Gongga Mountain, SW China. PLoS ONE 8. DOI: ARTNe7295210.1371/journal .pone. 0072952. 
Svetlova, Y. I. and Gradusov, B. P. (1985). Mineral and chemical composition of soils from the southern taiga subzone of the Ural region. Soviet Soil Science 17, 97-102.

Takeda, M., Nakamoto, T., Miyazawa, K., and Murayama, T. (2009). Phosphorus transformation in a soybeancropping system in Andosol: effects of winter cover cropping and compost application. Nutri. Cycl. Agroecosyst. 85, 287-297. DOI: $10.1007 / \mathrm{s} 10705-009-9267-6$.

Taranto, M. T., Adams, M. A., and Polglase, P. J. (2000). Sequential fractionation and characterisation (P-31-NMR) of phosphorus-amended soils in Banksia integrifolia (L.f.) woodland and adjacent pasture. Soil Biol. Biochem. 32, 169-177. DoI: 10.1016/S0038-0717 (99) 00138-8.

Tchienkoua and Zech, W. (2003). Chemical and spectral characterization of soil phosphorus under three land uses from an Andic Palehumult in West Cameroon. Agric. Ecosyst. Environ. 100, 193-200. Dor: 10.1016/S01678809 (03) 00195-6.

Thomas, S. M., Johnson, A. H., Frizano, J., Vann, D. R., Zarin, D. J., and Joshi, A. (1999). Phosphorus fractions in montane forest soils of the Cordillera de Piuchue, Chile: biogeochemical implications. Plant Soil 211, 139-148. DOI: $10.1023 / \mathrm{A}: 1004686213319$.

Tiessen, H., Abekoe, M. K., Salcedo, I. H., and Owusu-Bennoah, E. (1993). Reversibility of phosphorus sorption by ferruginous nodules. Plant Soil 153.1, 113-124. Dor: 10.1007/bf00010550.

Tiessen, H., Salcedo, I. H., and Sampaio, E. V. S. B. (1992). Nutrient and Soil Organic-Matter Dynamics under Shifting Cultivation in Semiarid Northeastern Brazil. Agric. Ecosyst. Environ. 38, 139-151. Dor: 10. 1016/01678809 (92) 90139-3.

Tolchelnikov, Y. and Gurov, A. (1985). Seasonal dynamics of iron aluminum and silicon compounds in sandy soils of southern taiga in the european USSR. Soviet Soil Science 17, 32-48.

Townsend, A. R., Asner, G. P., Cleveland, C. C., Lefer, M. E., and Bustamante, M. M. C. (2002). Unexpected changes in soil phosphorus dynamics along pasture chronosequences in the humid tropics. fournal of Geophysical Research-Atmospheres 107. DoI: Artn806710.1029/2001jd000650.

Tran, T. S., Giroux, M., and Fardeau, J. C. (1988). Effects of Soil Properties on Plant-Available Phosphorus Determined by the Isotopic Dilution Phosphorus-32 Method. Soil Sci. Soc. Am. F. 52.5, 1383-1390. DoI: 10.2136/sssaj 1988. $03615995005200050033 x$.

Trasar-Cepeda, M. C., Gilsotres, F., and Guitianojea, F. (1990). Relation between Phosphorus Fractions and Development of Soils from Galicia (Nw Spain). Geoderma 47, 139-150. DoI: 10.1016/0016-7061 (90) 90051A.

Turan, M., Ataoglu, N., and Sahin, F. (2007). Effects of Bacillus FS-3 on growth of tomato (Lycopersicon esculentum L.) plants and availability of phosphorus in soil. Plant Soil and Environment 53, 58-64.

Turrion, M. B., Glaser, B., Solomon, D., Ni, A., and Zech, W. (2000). Effects of deforestation on phosphorus pools in mountain soils of the Alay Range, Khyrgyzia. Biol. Fertil. Soils 31, 134-142. DoI: 10.1007/s003740050636.

Ubugunov, L. L., Ubugunova, V. I., and Mangataev, T. D. (1998). Phosphate reserves of the most typical alluvial soils of the Selenga river basin. Eurasian Soil Sci. 31, 61-66.

Valdespino, P., Romualdo, R., Cadenazzi, L., and Campo, J. (2009). Phosphorus cycling in primary and secondary seasonally dry tropical forests in Mexico. Ann. For. Sci. 66. Dor: Artn10710.1051/Forest: 2008075.

Vaychis, M. V. (1988). Specific characteristics of Brown Forest soil formation on ancient alluvium. Soviet Soil Science 20, 50-56.

Verma, S., Subehia, S. K., and Sharma, S. P. (2005). Phosphorus fractions in an acid soil continuously fertilized with mineral and organic fertilizers. Biol. Fertil. Soils 41, 295-300. DOI: 10.1007/s00374-004-0810-y.

Vinegla, B., Garcia-Ruiz, R., Lietor, J., Ochoa, V., and Carreira, J. A. (2006). Soil phosphorus availability and transformation rates in relictic pinsapo fir forests from southern Spain. Biogeochemistry 78, 151-172. DoI: 10.1007/s10533-005-3698-1.

Vu, D. T., Tang, C., and Armstrong, R. D. (2008). Changes and availability of P fractions following 65 years of P application to a calcareous soil in a Mediterranean climate. Plant Soil 304, 21-33. Dor: 10 .1007/s11104$007-9516-\mathrm{x}$.

Wagar, B. I., Stewart, J. W. B., and Moir, J. O. (1986). Changes with Time in the Form and Availability of Residual Fertilizer Phosphorus on Chernozemic Soils. Can. F. Soil Sci. 66, 105-119.

Wang, G. P., Liu, J. S., Wang, J. D., and Yu, J. B. (2006). Soil phosphorus forms and their variations in depressional and riparian freshwater wetlands (Sanjiang Plain, Northeast China). Geoderma 132, 59-74. DoI: 10.1016/j . geoderma.2005.04.021.

Wang, X., Lester, D. W., Guppy, C. N., Lockwood, P. V., and Tang, C. (2007). Changes in phosphorus fractions at various soil depths following long-term $P$ fertiliser application on a black vertosol from south-eastern Queensland. Aust. F. Soil Res. 45, 524-532. Dor: 10.1071/SR07069.

Weiss, L., Shiels, A. B., and Walker, L. R. (2005). Soil impacts of bristlecone pine (Pinus longaeva) tree islands on alpine tundra, Charleston Peak, Nevada. Western North American Naturalist 65, 536-540. 
Wright, R. B., Lockaby, B. G., and Walbridge, M. R. (2001). Phosphorus availability in an artificially flooded southeastern floodplain forest soil. Soil Sci. Soc. Am. F. 65, 1293-1302.

Xavier, F. A. D., Almeida, E. F., Cardoso, I. M., and Mendonca, E. D. (2011). Soil phosphorus distribution in sequentially extracted fractions in tropical coffee-agroecosystems in the Atlantic Forest biome, Southeastern Brazil. Nutri. Cycl. Agroecosyst. 89, 31-44. DOI: 10.1007/s10705-010-9373-5.

Xu, G., Sun, J. N., Xu, R. F., Lv, Y. C., Shao, H. B., Yan, K., Zhang, L. H., and Blackwell, M. S. A. (2011). Effects of air-drying and freezing on phosphorus fractions in soils with different organic matter contents. Plant Soil and Environment 57, 228-234.

Xue, Q. Y., Shamsi, I. H., Sun, D. S., Ostermann, A., Zhang, Q. C., Zhang, Y. S., and Lin, X. Y. (2013). Impact of manure application on forms and quantities of phosphorus in a Chinese Cambisol under different land use. $\mathcal{F}$. Soils Sediments 13, 837-845. DOI: 10.1007/s11368-012-0627-5.

Yavitt, J. B., Harms, K. E., Garcia, M. N., Mirabello, M. J., and Wright, S. J. (2011). Soil fertility and fine root dynamics in response to 4 years of nutrient $(\mathrm{N}, \mathrm{P}, \mathrm{K})$ fertilization in a lowland tropical moist forest, Panama. Austral Ecol. 36, 433-445. DOI: 10.1111/j.1442-9993.2010.02157.x.

Zhang, J., Li, M., Liu, S., Liu, Y. J., Zhang, L. Q., Cao, Q., and Sun, D. Z. (2011). Seasonal variations and bioavailability of inorganic phosphorus in soils of Yeyahu Wetland in Beijing, China. Int. F. Sediment Res. 26, 181-192.

Zhang, L., Wu, Y., Wu, N., Luo, P., Liu, L., and Hu, H. Y. (2011). Impacts of Vegetation Type on Soil Phosphorus Availability and Fractions near the Alpine Timberline of the Tibetan Plateau. Pol. f. Ecol. 59, 307-316.

Zhang, Q., Wang, G. H., Feng, Y. K., Sun, Q. Z., Witt, C., and Dobermann, A. (2006). Changes in soil phosphorus fractions in a calcareous paddy soil under intensive rice cropping. Plant Soil 288, 141-154. DOI: 10.1007/ s11104-006-9100-9.

Zhang, T. Q., MacKenzie, A. F., Liang, B. C., and Drury, C. F. (2004). Soil test phosphorus and phosphorus fractions with long-term phosphorus addition and depletion. Soil Sci. Soc. Am. F. 68, 519-528.

Zheng, Z. M., MacLeod, J. A., and Lafond, J. (2004). Phosphorus status of a Humic Cryaquept profile in a frigid continental climate as influenced by cropping practices. Biol. Fertil. Soils 39, 467-473. DOI: 10.1007/s00374004-0735-5.

Zohar, I., Shaviv, A., Young, M., Kendall, C., Silva, S., and Paytan, A. (2010). Phosphorus dynamics in soils irrigated with reclaimed waste water or fresh water - A study using oxygen isotopic composition of phosphate. Geoderma 159, 109-121. DoI: 10.1016/j.geoderma.2010.07.002.

Zubillaga, M. S. and Giuffre, L. (1999). Soil phosphorus mobilization in different taxonomic orders. F. Plant Nutr. Soil Sci. 162, 201-205. DOI: 10.1002/(Sici) 1522-2624(199903) 162:2<201: : Aid-Jpln201>3. 0 . Co;2-9. 